\title{
Social-Environmental Conflicts in Chile: Is There Any Potential for an Ecological Constitution?
}

\author{
Maite Berasaluce ${ }^{1,+} \mathbb{D}$, Pablo Díaz-Siefer ${ }^{2,3,+} \mathbb{D}$, Paulina Rodríguez-Díaz ${ }^{4}\left(\mathbb{D}\right.$, Marcelo Mena-Carrasco ${ }^{5}$, \\ José Tomás Ibarra $^{6,7}$ (D), Juan L. Celis-Diez ${ }^{3,5}$ (D) and Pedro Mondaca ${ }^{3, *(D)}$
}

check for updates

Citation: Berasaluce, M.; Díaz-Siefer, P.; Rodríguez-Díaz, P.; Mena-Carrasco, M.; Ibarra, J.T.; Celis-Diez, J.L.; Mondaca, P. Social-Environmental Conflicts in Chile: Is There Any Potential for an Ecological Constitution? Sustainability 2021, 13, 12701. https:/ / doi.org/10.3390/su132212701

Academic Editors: Troy D. Abel, Debra J. Salazar, Patrick D. Murphy and Jonah White

Received: 28 June 2021

Accepted: 10 November 2021

Published: 17 November 2021

Publisher's Note: MDPI stays neutral with regard to jurisdictional claims in published maps and institutional affiliations.

Copyright: (c) 2021 by the authors Licensee MDPI, Basel, Switzerland. This article is an open access article distributed under the terms and conditions of the Creative Commons Attribution (CC BY) license (https:/ / creativecommons.org/licenses/by/ $4.0 /)$.
1 Independent Researcher, Viña del Mar 2560000, Chile; maite.berasaluce@pucv.cl

2 Centro Regional de Investigación e Innovación para la Sostenibilidad de la Agricultura y los Territorios Rurales_CERES, Quillota 2260000,Chile; pablo.diaz@pucv.cl

3 Escuela de Agronomía, Pontificia Universidad Católica de Valparaíso, Quillota 2260000, Chile; juan.celis@pucv.cl

4 Programa de Doctorado en Geografía, Instituto de Geografía, Pontificia Universidad Católica de Chile, Macul 7820436, Chile; parodriguez6@uc.cl

5 Centro de Acción Climática, Pontificia Universidad Católica de Valparaíso, Valparaíso 2260000, Chile; marcelo.mena@pucv.cl

6 ECOS (Ecosystem-Complexity-Society) Co-Laboratory, Center for Local Development (CEDEL) \& Center for Intercultural and Indigenous Research (CIIR), Campus Villarrica, Pontificia Universidad Católica de Chile, Villarrica 4930000, Chile; jtibarra@uc.cl

7 Department of Ecosystems, Faculty of Agriculture and Forest Sciences \& Center of Applied Ecology and Sustainability (CAPES), Pontificia Universidad Católica de Chile, Santiago 8330025, Chile

* Correspondence: pedro.mondaca@pucv.cl

+ These authors contributed equally to this work.

Abstract: Social unrest is on the rise worldwide amid deepening inequalities, environmental degradation, and job crises worsened by increasing social-environmental conflicts. In Chile, a social revolt in 2019 resulted in a national referendum in 2020. An ample majority (78.3\% vs. $21.7 \%$ ) voted to draft a new constitution to replace the current constitution drawn up under dictatorship. The result led to the emergence and empowerment of several organizations demanding an "ecological constitution". In this context, we aim to analyze: (1) the main social-environmental conflicts in Chile and how they are related to the country's current constitution, and (2) the potential drafting of an ecological constitution that addresses these conflicts. Across different industries in Chile, we observed common problems that are intrinsically related to the current constitution. This relationship seems to be perceived by Chilean citizens since a survey carried out in May 2021 found 79\% support for an ecological constitution. Moreover, 105 of the 155 delegates to the constitutional convention proposed three or more environmental principles to be included in the new constitution. A potential ecological constitution entails principles that would improve the current situation of social-environmental conflicts in Chile. Based on our analysis, we recommend the establishment of watershed-based "territorial rights" in the new Chilean constitution to improve sustainability and environmental justice.

Keywords: social turmoil; socio-environmental; water; land; indigenous; pollution; territorial rights; sustainability; environmental justice; environmental constitution

\section{Introduction}

Social unrest is on the rise worldwide, with millions of people demonstrating a demand for environmental justice, jobs, equity, and democratic freedom. In November 2020, for example, 250 million people in India participated in a protest demanding that the government repeal laws that would deregulate agricultural activity. Similarly, in Hong Kong, protests against an extradition bill revived a pro-democracy movement against mainland China's involvement in the semi-autonomous region [1]. South American countries are not immune to these increasing social-environmental crises. 
In October 2019, an unprecedented social uprising came to Chile. Protestors demanded an end to decades of socioeconomic inequality and a new constitutional order incorporating a baseline of social-environmental protection [2-4]. This baseline does not exist under the current constitution. Established in 1980 during the Pinochet military dictatorship, the old constitution imposed a neoliberal economic development model based mainly on economic liberalization, accompanied by mass privatizations of natural resources and state-owned companies. As a result, Chile has become the most extractive economy in the OECD and the Americas [5]. The Pinochet constitution was reformed in 2005 without taking social-environmental concerns into account.

Despite the COVID-19 pandemic, a referendum on the drafting of a new constitution was held on 25 October 2020, a year after the outbreak of social unrest. The option of writing a new constitution was overwhelmingly approved, with $78.28 \%$ support against $21.72 \%$ for maintaining the current constitution. Turnout (50.9\%) was unprecedentedly high in a context of voluntary voting. In eight local communities with some of the country's worst environmental conditions - referred to as "sacrifice zones" — the option of drafting a new constitution was approved by over $90 \%$ [6] with a turnout of $50.6 \%$ [7].

Given this overwhelming vote, several existing and emerging organizations started to demand an "ecological constitution" as an integral solution to environmental injustices [8,9]. Environmental injustice, commonly regarded as part of social injustice, normally refers to the unjust distribution of unhealthy environments under which communities with low-income and/or racial and ethnic minority residents are exposed to environmental and health hazards [10-12]. In the election of the 155 delegates to the convention in 2021, 105 of those elected campaigned for the inclusion of at least three environmental principles in the new constitution, as presented to the electoral college in their official campaign programs [7]. The analyzed principles were protecting biodiversity, addressing climate change, sustainability, water rights, protections for first nations, nature rights, the right to a safe environment, glaciers, peatland, or ocean protection, and finally, environmental justice.

In this context, one could ask: How do social-environmental conflicts occur? Would an ecological constitution improve perceptions of environmental justice in Chile? To address these questions, this paper seeks to: (1) analyze how social-environmental conflicts occur in different national cases, looking at whether they are related to the current constitution, and (2) analyze and discuss how to improve the social-environmental situation in the scenario of Chile's constitutional process and the possibility of an ecological constitution.

For the first objective, we identified some of the major social-environmental conflicts in the country related to industrial activities (Section 2). Specifically, we searched for the main social-environmental conflicts in the national and international media (mostly newspapers) and selected the cases we judged most relevant. We also included nonindustrial cases with important implications for the environment and/or human welfare. All the cases selected were analyzed in terms of how current social-environmental conflicts negatively affect present and future generations. For the analysis, we included the following information: related legal body, data from national reports, and scientific literature. Finally, we performed a general diagnosis of social-environmental conflicts (Section 3).

For the second objective, we reviewed national and international contexts of demand for the inclusion of social-environmental dimensions in a constitution (Section 4). Specifically, we reviewed environmental constitutions around the world as a reference, along with the national historical process of advancement of the idea of an ecological constitution. We also assessed the current importance of the environment for citizens through a survey and by analyzing the election campaigns of delegates to the constitutional convention. Finally, we offer some recommendations for the process of writing the new constitution (Section 5).

\section{Social-Environmental Conflicts in Chile}

\subsection{General Context}

The National Institute of Human Rights (INDH) has a public database with information about Chile's major social-environmental conflicts [13]. This database shows the 
number of conflicts in each of the fifteen Chilean administrative regions. However, we analyzed the conflicts by natural macroregions that are not administrative but helpful for grouping regions with similar climatic conditions (Figure 1). As shown in Figure 1a, conflicts are more common in northern and central Chile than in the south of the country. The distribution of the different productive sectors and industries does not follow a territorial pattern and is heterogeneous (Figure $1 b$ ). This territorial heterogeneity is a challenge that must be considered in drawing up a new constitution in order to advance towards sustainable development.

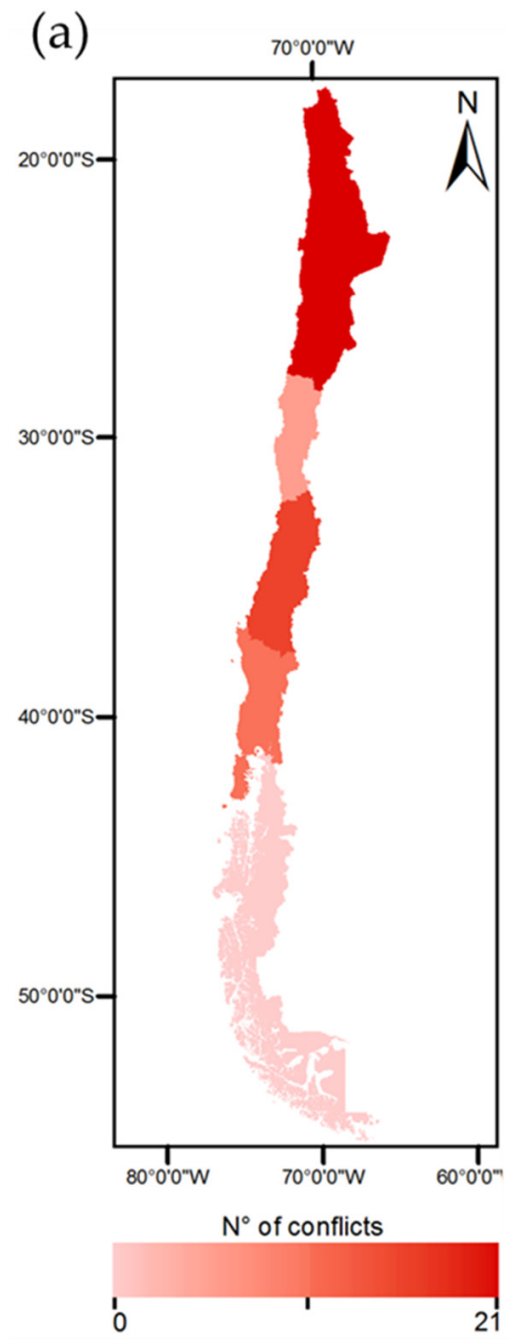

(b)

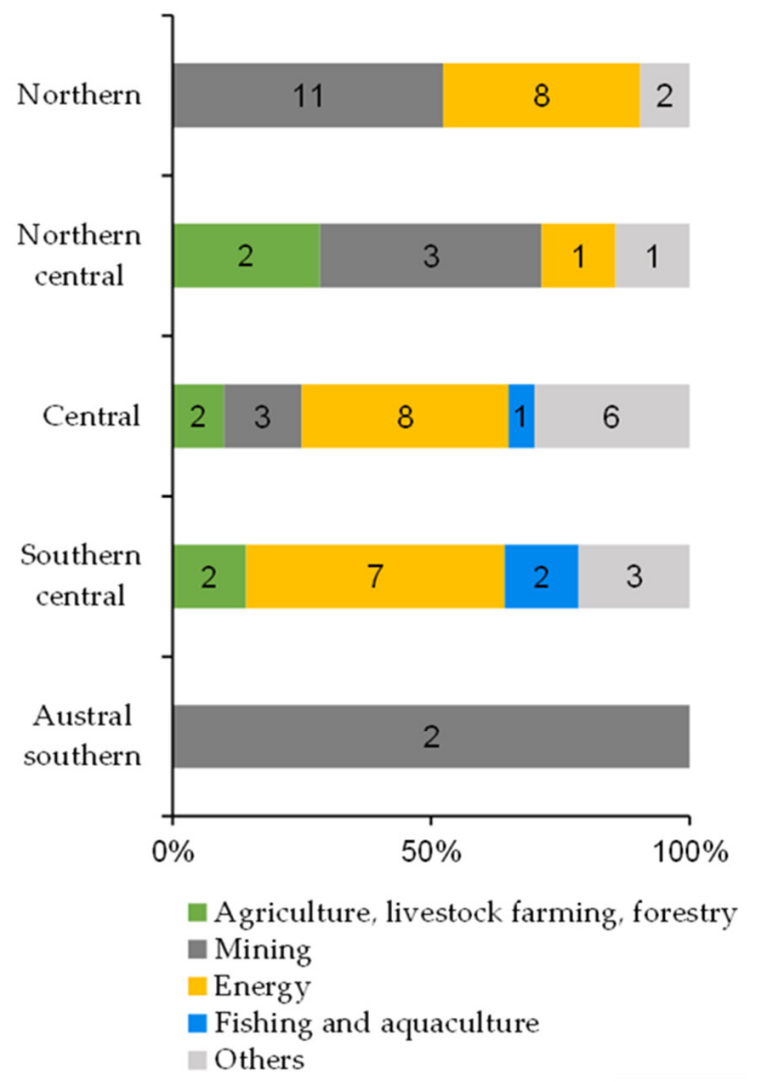

Figure 1. Social-environmental conflicts in Chile (adapted from the platform of the National Institute of Human Rights (INDH) [13]): (a) Map of Chile showing the number of social-environmental conflicts by geographical macroregion; (b) Relative participation of different industrial activities in social-environmental conflicts by geographical macroregion.

\subsection{Cases Involving Agriculture, Livestock, and Forestry}

\subsubsection{Water Use: The Case of Petorca Province}

Under Chile's 1980 Constitution, water rights have the status of "property rights" [14]. Similarly, the 1981 Water Code [15] defined water as an economic good and separated the ownership of water rights from ownership of the land [16]. For decades, therefore, water has been treated as an economic good that is tradable on the market [17], leading to abysmal inequity (Gini coefficient for water rights $=0.99$ ), with $79 \%$ of the total volume of water available in the system owned by $1 \%$ of water users [18]. 
The agricultural sector is Chile's main water user (72\% of the total available) [19]. High water use, the modernization of irrigation technologies, and the ratification of international commercial treaties have been crucial in strengthening intensive agriculture and, particularly, fruit production. The area under fruit increased by 113,038 ha (48\%) between 2003 and 2018) [20]. However, the agribusiness model has been criticized because of the social-ecological impacts of large-scale agricultural production on the territories [21,22].

The best-known conflict over water use is the case of Petorca Province (Mediterranean central Chile), which has been reported in the national and international media (e.g., $[23,24])$. In this part of Chile, climate change and other climatic events have resulted in a reduction in precipitation [25,26] that was particularly marked between 2010 and 2018 , with mean rainfall deficits of 20-40\% [27]. Indeed, dendrochronological research in the Petorca watershed shows that the current drought is the most severe in a 700-year streamflow reconstruction [28].

Despite water scarcity, private water rights, estimated on the basis of historical river flow under normal pre-drought conditions, allow their owners to choose to use water freely. Consequently, while there are approximately 4807 ha of irrigated avocado orchards in the Petorca Province [29], several towns have no access or insufficient access to drinking water [28]. Moreover, water scarcity has increased demand for groundwater reservoirs, reducing the water level in $75 \%$ of wells in the Petorca Province [30]. The lower the water level, the higher the cost involved, which small farmers can generally not afford. According to Tamayo and Carmona (2019), "access to water is in a direct relationship to the economic capacity of the farmer" (in [17]).

Limited access to water for domestic use compromises human rights [31,32] and food sovereignty [33] and threatens rural communities [34]. However, access to water is not recognized under Chile's current constitution [14]. Since limited rainfall has become a constant scenario in semiarid areas of Chile [35], it is critical to establish effective policies for managing water sustainably accounting for both the hydrological cycle and equity. Law 18.450 [36] has promoted private investment in irrigation efficiency through state subsidies. However, water saved at the farm scale typically does not reduce water consumption at the watershed scale [37], probably because the saved water would be used by the same farmers and not necessarily by other users. A reform of the Water Code proposed in 2014 [38] would have, among other modifications, replaced free and perpetual water rights with temporary concessions, but it has been blocked by the country's main agricultural associations [17].

\subsubsection{Land Degradation: The Case of Soil Erosion}

In the last five decades, the main land-use changes in central Chile have been from forest and shrubland to farmland [39] and, in south-central Chile, to plantations of exotic trees [40]. This transition has caused soil erosion and loss of biodiversity, along with several social-environmental conflicts (e.g., rural exodus, the closure of rural schools and hospitals, land concentration, community displacement, etc.) [39,41,42]. Soil erosion (i.e., the loss of fertile soil) is one of the most serious threats facing world food production [43]. The greater the level of erosion, the more energy is spent merely to offset losses of nutrients on-site and environmental and social issues off-site, including eutrophication, damage to public health, and increased water treatment costs [44]. In addition, the loss of biodiversity impacts social welfare and the provision of a number of ecosystem services [45,46].

According to a national report, $49 \%$ of Chile's surface has eroded soil, a figure that is approximately three times higher in the north than in the south [47]. Youlton et al. [48] found a loss of soil of $20 \mathrm{t} \mathrm{ha}^{-1}$ during the first year of an avocado plantation on a hillside, although mitigation measures reduced erosion by $90 \%$. However, despite the benefits of these measures, they are not mandatory and private property rights allow landowners to manage soil freely [49]. Even though soils are a critical environmental resource for a country's development, this is not recognized as such by the current Chilean constitution [14]. 
Moreover, the Chilean forestry model promotes exotic plantations of pines and eucalyptus through state subsidies [50,51]. As a result, the forest industry had more than 3 million ha of plantations in 2019 [52] of which $64 \%$ was in the hands of only three companies [42]. Indeed, the neoliberalization supported by Chile's current constitution has influenced the social constructions of natural resources policy [53]. There also is evidence of a series of social-environmental conflicts in the territories where the plantations are located (analyzed in [54]). For example, exotic tree plantations limit agricultural activities by reducing water availability and causing soil erosion at a watershed scale [55-57]. Furthermore, forest plantations increase $\mathrm{CO}_{2}$ emissions [50] and reduce biodiversity by replacing native forest. This negatively impacts many families dependent on non-wood forest products for their livelihoods [54]. Finally, pine and eucalyptus are pyrophytic or flammable species and favor fires [58,59] as witnessed in the massive wildfires Chile endured in 2017.

These environmental issues have direct social consequences for local communities [46], even leading to violent conflicts in some rural areas of the Araucanía Region, as reported by Reyes and Nelson [42]. These authors conclude that citizens have been awaiting greater government involvement through new regulation or a change in policy emphasis, but governments have had other priorities, prioritizing economic growth. Moreover, it is important to note that, while soil formation is a process on a millennia scale [60], a high rate of soil degradation is occurring in just decades. Therefore, the current Chilean model is ethically questionable since it threatens future generations' right to the use of healthy and productive soils, the very basis of current growth and well-being.

\subsection{Cases Involving the Mining Industry}

\subsubsection{Environmental Pollution: The Case of Puchuncaví Valley}

Chile is the world's main copper producer and the industry accounts for most of the country's mining export earnings [61,62]. However, since mining activities are commonly associated with environmental pollution [63], perceptions of environmental injustice often arise once mining activities violate the right to live in an environment free of contaminants. The Ventanas copper smelter in the Puchuncaví Valley (coast of central Chile) is the country's most emblematic example of the impact of mining on local communities. One of the most remembered environmental disasters in this area occurred in 2011 when accidental atmospheric emissions of toxic sulfur dioxide from the state-owned smelter caused the acute intoxication of 31 children and 7 adults at a rural school in the Puchuncaví Valley [64]. However, long-term emissions could be even more serious than specific emergency episodes.

Atmospheric pollution by the Ventanas copper smelter has led to chronic soil contamination with trace elements [65]. A recent assessment of the involuntary intake of re-suspended soil and dust by the Puchuncaví Valley's inhabitants showed that high arsenic concentrations in soil and dust are associated with a high risk of adverse health effects on children. This level of contamination would be considered "unacceptable" under the standards of the United States Environmental Protection Agency (US EPA) [66,67]. Pollution also threatens food security since consumption of vegetables grown near the Ventanas copper smelter would lead to an intake of arsenic six times higher than for vegetables from an unpolluted area [68]. Similarly, a high concentration of arsenic and other trace elements has been detected in locally sourced seafood, even exceeding some reference values established by Food Health Regulations [69,70]. Although Chile's current constitution states the right to live in a pollution-free environment (Article 19 in [14]), this has been violated in the Puchuncaví Valley for decades.

The case of the Puchuncaví Valley also involves other industries, such as a coal-fired power plant complex, oil industries, liquefied gas terminals, and chemical industries. These facilities form the Ventanas Industrial Complex. Together, this complex has exceeded the concentration of sulfur dioxide in localities in the Puchuncaví Valley for several years $[71,72]$. This pollution caused desertification of the landscape, due to soil acidification 
and soil organic matter degradation $[65,73,74]$. Industrial activities also resulted in a loss of soil with various consequences for the local economy, health, and well-being [75].

These changes in the landscape and environmental conditions, in addition to land-use modifications, have resulted in an economic transition from tourism, fishing, and agriculture to industrial activities [75,76]. Initially, this industrial development met with interest and support among local inhabitants because of the activities' economic potential $[76,77]$. However, most of the taxes from these companies are not paid in the polluted localities but in Santiago (capital of Chile). Therefore, despite the important economic contribution of this industrial area, with its supposed benefits for Chilean society as a whole, the inhabitants of Puchuncaví suffer the injustice of several negative environmental externalities.

\subsubsection{Ecosystem Injustice and Indigenous People: The Case of the Atacama Desert}

The global boom in clean technologies has increased demand for electric cars in recent years and, consequently, for lithium as well [78,79]. At 8.6 million tons, Chile's lithium reserves are among the largest in the world [80], leading to important domestic and transnational investment in projects in the Atacama Desert, one of the driest deserts in the world. These projects require large amounts of water for their industrial processes and are, therefore, increasingly located near groundwater resources, overlapping with nature conservation areas, biodiversity protection sites, and communal lands claimed by indigenous peoples [81].

The requirements of mining production have generated enormous pressure on the water resources of the ancestral territories of Lican Antai, Quechua, and Aymara indigenous communities [81,82]. In this context, a group of researchers signed the "Tarapacá Declaration" in 2018, drawing attention to the urgent need to change how human societies have been using water in the Atacama Desert, based on a historical trajectory spanning several millennia [83]. This Declaration defines water in the Atacama Desert as a non-renewable resource at the economic scale of extraction of this element, which depends fundamentally on fossil waters that have accumulated for millennia in the highlands of the Desert. Since Chile's Water Code helps ensure that the right to use water goes to the highest bidder (Section 2.2.1), it is easier to award these rights to corporate actors, rather than to take measures for the resource's protection. The resulting disparities exemplify distributive, procedural, and recognition environmental injustices for the Indigenous communities of the Atacama Desert [84]. This explains why the relationship between mining companies and local communities has worsened [85].

As well as being vital for the survival of plants, animals, and humans, water is a fundamental social component of Andean communities. In particular, the Lican Antai community asserts that "water is a being" and acknowledges its importance for social well-being, given its cosmological belief in engaging with water as a potent spiritual force [86,87]. This illustrates how Indigenous environmental justice demands sustainability thinking to recognize nonhuman entities [88]. Moreover, water-related flora and fauna are also threatened since they inhabit fragile ecosystems with a high level of species endemism and diversity [89-93].

\subsection{Cases Involving the Energy Industry}

\subsubsection{Air Pollution: The Case of Northern Chile}

Coal-fired power plants are a major source of global pollution and are one of the main agents of local air pollution [94]. They represent a health risk for exposed communities because they release atmospheric pollutants in their combustion processes. Despite this, almost $40 \%$ of Chile's electricity is produced by burning coal $[95,96]$ and several of these power plants have been operating for more than 40 years, with technologies considered obsolete.

Cortes et al. [97] used Health Ministry statistics on hospital discharges (morbidity) and deaths (mortality) in the towns of Tocopilla, Mejillones, and Huasco (northern Chile), where some 20 coal-fired power plants operate. They evaluated the effects on cardiovascular, 
respiratory, and cancer health compared to localities without industrial facilities of this type. In Tocopilla, they found a $22 \%$ higher risk of dying compared to the country's general mortality rate, a $34 \%$ higher risk of falling ill, and a $76 \%$ higher risk of respiratory disease. Whereas, in Huasco, they found a $71 \%$ higher risk of dying from cardiovascular disease compared to the national average, a $381 \%$ higher risk of dying from cerebrovascular disease and, in the case of chronic respiratory diseases, a 239\% higher risk. Ruiz-Rudolph et al. [98] had previously reported similar results, showing that, in cities with power plants or smelters, mortality due to cancer and cardiovascular and respiratory causes increases by between $20 \%$ and $100 \%$, accompanied by a similar increase in rates of hospitalization for the same causes.

These studies underscore the energy matrix's high cost for the affected communities. Although Chile has launched a national decarbonization plan under the Paris Agreement, it is necessary to take into account the social-environmental cost that the operation of these plants has had by increasing the carbon tax accordingly.

\subsubsection{Human Resettlement: The Case of the Ralco Dam}

Renewable energy industries (REI) aim to reduce $\mathrm{CO}_{2}$ emissions and increase Chile's energy independence. However, in some cases, they have caused land conflicts. Specifically, they have been associated with social injustice because projects may transform or threaten indigenous natural or spiritual areas [99-103]. In Chile, an emblematic case is the conflict over the Ralco hydroelectric dam. It involved the resettlement of 675 people of whom some 500 belonged to a Mapuche-Pehuenche community [104].

The dam transformed the Biobío River from a sacred place for the Mapuche-Pehuenche community into an artificial lake, causing Punalka, the spirit of the river, to leave the community and bringing misfortune to the land and the people [99]. Moreover, the resettlement led to problems that included community atomization, the irregular practice of traditional ceremonies, and alcoholism [105]. This conflict occurred before Chile ratified ILO Convention 169 , which establishes the mandatory consultation of indigenous communities about projects by which they would be affected [106]. Today, despite the Convention's ratification, indigenous communities continue to fight against energy projects that are often considered a threat to local territories (with seven active cases to date) [13].

\subsection{Fishing and Aquaculture}

2.5.1. Overexploitation of Aquatic Resources: The Case of Chiloé and Chilean Patagonia

Traditionally, artisan fishing was crucial for the subsistence of the Chilotes, the inhabitants of the Chiloé archipelago [107] and a mix of Huilliche indigenous populations and Mestize. However, since 1969, the aquaculture industry has resulted in a process of modernization and globalization that has brought with it jobs, infrastructure development, and changes in people's expectations and aspirations [108]. However, the growth of salmon farming has also been marked by important social-ecological conflicts. Abundant evidence of its negative impacts on the environment has been published in the scientific literature [109-111]. The impacts include local eutrophication and biodiversity reduction downstream from the farms.

The environmental issues associated with salmon farming in Chile were recently reviewed by Quiñones et al. [111], who reported: (i) harmful algal blooms triggered by nutrients from salmon feed; (ii) the negative effect of pesticides used to control sea lice in salmon on some non-target species; (iii) the development of antibiotic-resistant bacteria in sediments due to the use of large quantities of antibiotics, and (iv) the effect of salmon escapes (introducing a high density of exotic species) on native biota at the ecosystem level. The most important environmental issue occurred in 2007 when the industry suffered a major health crisis. First there was a massive Caligus (salmon louse) outbreak and, later, an epidemic of infectious salmon anemia (ISA) caused mainly by the industry's negligence [111]. In March 2008, the New York Times published an article linking the massive use of antibiotics to control ISA-a health threat for consumers-with 
poor environmental conditions, with effects on both workers and local communities [112]. These problems resulted in a decline in salmon production and exports. The ISA virus reduced salmon output from 400,000 tons in 2005 to 100,000 tons in 2010 [113], entailing the dismissal of thousands of workers [114].

Chiloe is a clear example of the socio-ecological impacts of the aquaculture industry's degradation of water quality. The impacts include the displacement of local fishermen from their traditional fishing areas as a result of the privatization of common marine resources. The aquaculture industry excluded several organized actors [114], and decreased in catches due to the pollution of estuaries, with economic consequences for fisherfolk and their families. In addition, the salmon industry's sanitary crisis in 2007 triggered a socioeconomic crisis in Chiloé due to the sudden increase in unemployment. Since then, sanitary crises have become a regular occurrence and, for example, a sanitary crisis in May 2016 triggered the social turmoil known as "Chilotes' May" [108].

Salmon farming also has negative consequences for nature-based tourism, an important source of income for the local economy in Patagonia [115]. The seasonal overpopulation of small Patagonian towns, which lack the necessary infrastructure and facilities, leads to a series of socioeconomic conflicts. In this context, an environmental NGO reported that, despite job creation by the salmon industry, it has been blamed for helping to perpetuate poverty through precarious working conditions [116].

We note that the aquaculture industry per se is not unsustainable. However, aquaculture regulation is based on the neoliberal model of concessions of public goods. In the absence of territorial planning, this fosters the development of private property, without regulation or participation of the state. Chile's Civil Code defines coastal waters as public goods for public use that can be concessioned for private use. Moreover, there is no limit on the number of concessions in a given area, even in areas corresponding to indigenous communities. Current regulation is not even able to protect the industry against its own excessive practices, as shown by the 2016 red tide event in which the industry proved unable to manage 40,000 tons of salmon mortality $[117,118]$. Therefore, the new constitution should consider that the right to private property may not be above the common interest.

\subsection{Nonindustrial Environmental Injustices}

2.6.1. Deregulation in Rural Areas: The Case of Unplanned Land Subdivision

In Chile, there is no land-use planning instrument for rural areas, only sector-specific instruments that have caused various conflicts and deregulation in rural areas [119]. For example, Decree Law 3.516 on the Division of Rustic Properties permits the division of rural properties into lots of 0.5 ha, known as "parcelas de agrado", which are commonly used for housing $[120,121]$. This practice has changed land use from rural to urban, without proper urbanization planning and regulation. These lots are mostly bought by high-income people for a second home, with detrimental effects on rural life, including gentrification processes [121,122].

Thus, conflicts are generated between rural inhabitants and new neighbors over the use of space (e.g., roads and waste), and for scarce resources such as water [121-124]. Additionally, ownership subdivision negatively impacts wildlife [125]. This occurs because of the current political constitution, its laws and norms, which support a neoliberal model of development under which the private sector regulates the market for land and other natural resources. Contrarily, according to a review by the World Wildlife Fund (WWF) [126], 42\% (13 out of 31) constitutions in the world include spatial planning (Supplemental Material: Table S1).

\subsubsection{Access to Natural Places: The Case of Public Protected Areas}

Central Chile is a global hotspot for biodiversity, due to its high rates of both endemism and land-use change [127]. This area is dominated by agricultural and urban development at the expense of nature $[128,129]$. For instance, it is the macroregion with the smallest surface of public protected areas (0.6\%, including national reserves) whilst, in 2000-2017, 
vineyards increased their area by $40 \%$ and human demography reached $56 \%$ of the national population [29,130-132]. Conversely, the largest surface of public protected areas is in the Magallanes Region in the Austral macroregion, which is 2200 km south of Santiago with which it does not have a continuous connecting road. The remoteness of these Austral national parks implies unequal access as not everyone can afford the cost of travel to visit them. This is reflected in the higher level of education and income of visitors to the public protected areas compared to the Chilean average [133-136].

Unequal access to public protected areas is deemed an environmental injustice because, as well as playing a role in biodiversity conservation, they also contribute to human wellbeing. For instance, contact with nature and, specifically, biodiversity can decrease stress more significantly than urban green spaces [137] and can improve the functionality of the immune system [138-140]. Therefore, public protected areas should be accessible to most people, as they play an important role in sustainability by providing benefits to human health, probably promoting local economic development and environmental education, and conserving biodiversity. Chile's National Biodiversity Strategy 2017-2030 may help to improve the accessibility of protected areas since it considers the protection of $17 \%$ of ecologically representative ecosystems, meeting the United Nation's Aichi Biodiversity Target 11 [141,142]. However, in Chile, only 29\% of ecosystems currently meet Aichi Target 11 while $11 \%$ have no protection category and $22 \%$ have less than $1 \%$ of their area protected [141].

Similarly with the unequal access to protected areas, there is an unequal distribution of urban green areas associated with the socioeconomic income level of the inhabitants of Santiago, which represents an environmental injustice for the inhabitants of the city [143]. Access to green spaces in urban environments is also important. There is abundant scientific evidence about the importance of green areas for people's physical, mental, and psychological well-being [144-146]. Most cities in Chile have a low surface of green areas per inhabitant and this is, moreover, segregated in quantity and quality by income level [143].

\subsubsection{Urban Air Pollution: The Case of Santiago}

Air pollution is Chileans' main environmental concern. According to surveys by the Ministry of Environment, 33\% identified it as their top concern in 2014 [147] and 2020 [148]. Annual $\mathrm{PM}_{2.5}$ concentrations in Santiago have been reduced by over $70 \%$, from $69 \mu \mathrm{g} / \mathrm{m}^{3}$ in 1989 to $21 \mu \mathrm{g} / \mathrm{m}^{3}$ in 2019 [149,150]. Yet there are still approximately 70 days per year when air pollution standards are not met. Moreover, there are spatial patterns of air pollution under which municipal districts with a lower socioeconomic level have the worst air quality of $\mathrm{PM}_{10}$ and $\mathrm{PM}_{2.5}$ compared to wealthy districts [151-153].

Poorer urban Chileans suffer longer periods of unhealthy air and $21 \%$ more days with unhealthy levels of air pollution [151]. Air pollution is also related to the higher population density of lower-income areas [152]. These spatial patterns of poorer air quality have aggravated inequality and environmental injustice among socioeconomic groups in Santiago. This phenomenon of environmental injustice in the air quality of cities is not confined to developing economies. An extensive review in the United States documented that exposure to pollution and other environmental risks is unequally distributed by race and class [154]. Therefore, air pollution in Chile is not only an important environmental issue but also a social one that needs to be addressed in the new constitution.

\section{Diagnosis of Social-Environmental Conflicts in Chile and Relation with the Current Constitution}

\subsection{Systematic Analysis of the Cases Reviewed}

Social-environmental conflicts are inextricably linked to Chile's current constitution of the country, being one of the main reasons that property rights exist over land and water without considering the common good. According to a recent report by Bauer et al. [155], these conflicts may be the result of two Articles of the constitution. First, Article 19, No. 8 
states: "The law may establish specific restrictions on the exercise of certain rights or freedoms to protect the environment" and these "certain rights or freedoms" include property rights and the right to carry out economic activities. Second, Article 19, No. 23 refers to the "freedom to acquire ownership over all types of property except that which nature has made common to all people or which should belong to the entire Nation, and the law declares it so" and adds "... when the national interest demands it, a law passed by a qualified quorum may establish limitations of requirements for acquiring ownership over specific property."

Through these provisions, the free appropriation of property is enshrined as a general constitutional principle, thus elevating the right of private property over natural resource protection as the general rule of the legal system. The argument of Bauer et al. is reflected in the cases reviewed here. For example, as explained in Section 2.2.2, private land ownership has been conducive to erosion of the soil environmental matrix over a matter of years or decades while its genesis occurred on a geological scale (millennia). Thus, it should be considered a national heritage, rather than a private good. Similarly, property rights over water use are not controlled, leading to the abysmal inequity that exists and the simplistic vision of the water as a good to be traded (Sections 2.2.1 and 2.3.2).

Other issues are also related to laws and norms in addition the constitution. For example, the current constitution defends the right to live in a pollution-free environment (Article 19, No. 8 in [14]). This Article has been mentioned in emblematic court cases that have resulted in the rejection of projects such as Central Castilla (coal-fired, $2100 \mathrm{MW}$ power plant) and the lack of feasibility of the Punta Alcalde project [156]. It is also important in supporting environmental institutions and permitting air pollution attainment programs [157]. However, in many cases, this right has not been fulfilled. For example, Chile has no soil norms and, despite scientific evidence of contamination in some mining areas, there is, therefore, no reference to validate this contamination in legal terms (Section 2.3.1). In contrast, air and water environmental matrixes do have norms on quality. However, as shown in Sections 2.4.1 and 2.5.1 above, the current constitution and norms are insufficient and pose a challenge for the drafting of a new constitution in terms of how to complement Article 19.

The similarities found between social-environmental conflicts in different industries in Chile (Figure 2) suggest that their origin lies in a systematic problem, rather than problems attributed to a particular industry. The cases we analyzed are part of the reason for social discontent and perceptions of environmental injustice. These perceptions were one of the triggers of the social turmoil that occurred in Chile in 2019, generating an unprecedented lack of governability. Conversely, Chile has long had some of the highest declared support for environmental regulation in the developing world [158], with a large majority associating climate change with anthropogenic causes [159] or supporting a green recovery in the wake of the COVID-19 pandemic. Accordingly, Chile can serve as a global example by drafting a new constitution that addresses environmental issues and seeks to achieve environmental justice within a progressive and modern legal framework.

\subsection{Centralization in Chile}

According to the current constitution, the State of Chile is unitary, its territory is divided into regions, and the law is intended to ensure that its administration is functionally and territorially decentralized (Article 3 in [14]). Nevertheless, Chile is one of the most centralized countries in the OECD [160]. Government spending is low (22\% of GDP) and, out of that spending, only a fraction is delivered by local governments (12\% of all government spending), making government action highly centralized and disconnected from the territory [159]. Alternatively, decentralization, as an approach for increased capacity at the local level, is key to fostering action on territorial sustainability [160]. In the last decade, some signs of progress towards effective decentralization have been seen as, for example, the election of regional councils (as from 2013) [161] and regional governors (as from 2021) [162]. However, the nature of their tasks is mainly administrative, with a 
funding arrangement in line with the national development policy; in other words, decision making is still mainly defined by the central government [159].

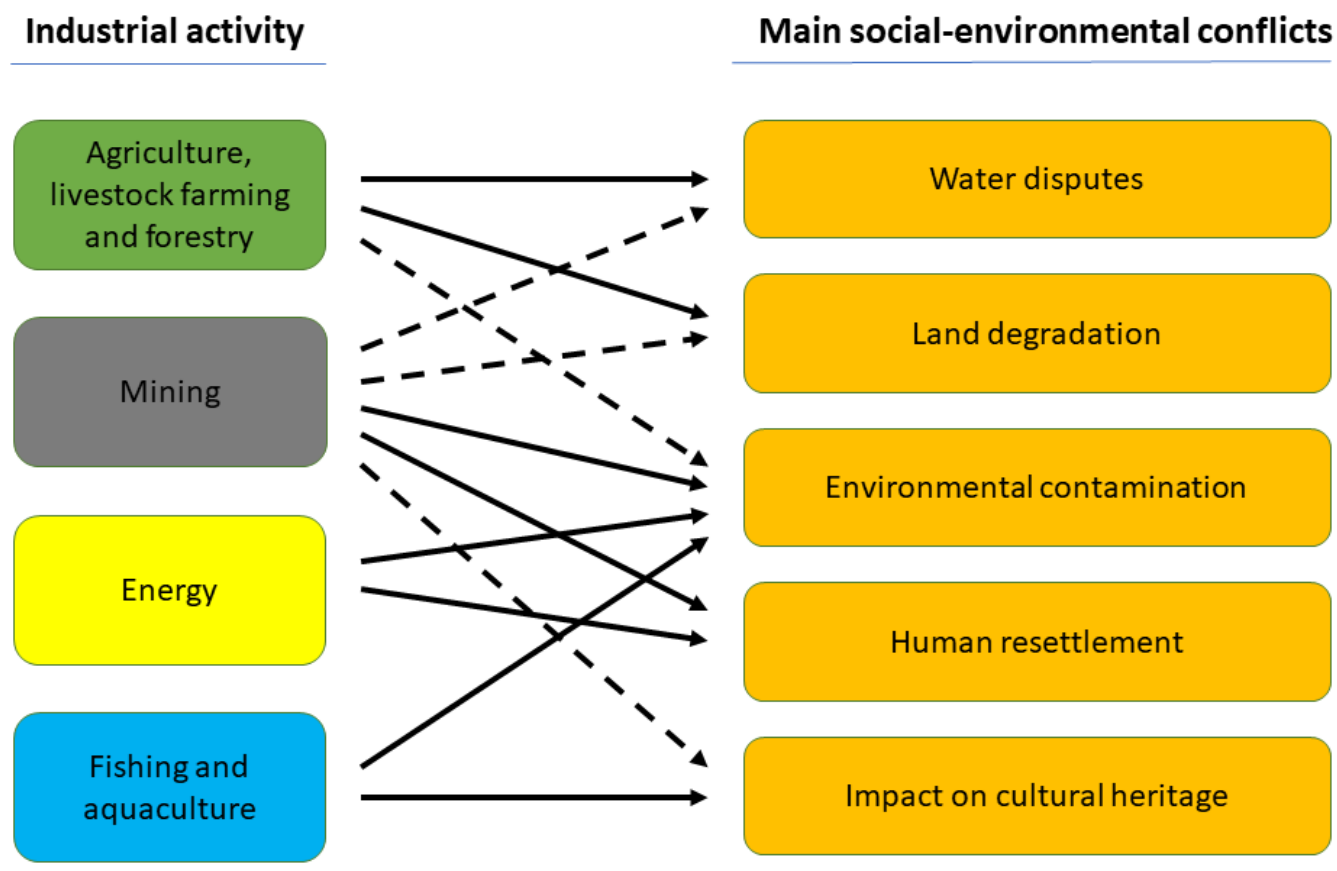

Figure 2. Summary of the main social-environmental conflicts associated with the industries analyzed. Solid and dashed arrows imply strong and medium relations respectively, according to our assessment.

Centralization is also reflected in the distribution of national revenues. Companies pay taxes where the owner lives, or where their headquarters are located. For large companies, this is generally Santiago [163]. As a consequence, $80.1 \%$ of national sales are attributed to the Santiago Metropolitan Region and only just under $20 \%$ to the country's other 15 regions [164]. These data partly explain the social-environmental issues associated with industrial activities. For example, mining and forestry make an important contribution to national fiscal revenues but this does not lead to local development in the territory where the environmental externalities occur. Moreover, this is aggravated by how industries develop their activities as this also conditions the development of future generations in those territories (Sections 2.2.2 and 2.3.2).

The centralization of environmental matters has most recently been illustrated by the Dominga mining project. It was approved by the Environmental Assessment Commission, comprising regional ministerial secretaries (representatives in the regions of central government ministries, appointed by the President of Chile), the regional director of the Environmental Assessment Service and a presidential delegate, or, in other words, without decision-making capacity on the part of the regional authorities. The project involves the construction of an iron and copper mine and a port in La Higuera (northern Chile). This mining-port project would be close to a marine reserve of key importance for the conservation of its great biodiversity [165]. Almost 80\% of the world's population of Humboldt penguins, a species declared vulnerable by the International Union for Conservation of Nature (IUCN), is found in this reserve [166]. Interestingly, the recently elected governor of the area was not allowed to participate or vote on this project. In line with the present review, this triggered social unrest, especially in neighboring cities $[167,168]$. 


\section{Towards an Ecological Constitution}

\subsection{International Constitutions with an Environmental/Ecological Approach}

Environmental constitutions have become increasingly common $[169,170]$. They must contain some key principles such as the rights of nature, the principle of sustainability, judicial receptivity, and rights and obligations relating to climate change [171,172]. The rights of nature were highlighted in the Universal Declaration of the Rights of Nature. Several nations incorporated this principle in their constitutions including Germany, Sudan, Kuwait, Ecuador, and Bolivia $[170,171]$.

The principle of sustainability, which seeks to ensure the preservation of all biotic and abiotic elements for future generations, is one of the most common principles in different constitutions (51.6\%, Supplementary Material: Table S1) according to a study of 31 constitutions around the world by the WWF [126]. Similarly, judicialization, which refers to the remediation of environmental damage or compensation, is a common component of constitutions (58.1\%, Supplementary Material: Table S1), as, for example, in Spain, Costa Rica, Mexico, and South Africa. On the other hand, climate change is one of the most scarce components, found only in Ecuador and the Dominican Republic [126,171]. Chile's current constitution does not consider any of the above components.

An ecological constitution goes a step beyond an environmental constitution, considering the territorial difference and incorporating the notion of the ecosystem and a social-ecological system. In this way, territories' ecological functions and biodiversity are protected, organizing the territory by ecosystems or hydrographic watersheds. Thus, each ecosystem's carrying capacity is considered under the social-ecological framework of earth stewardship and sustaining life in a rapidly changing world [172-175]. Collins recently associated ecological constitutions with the concept of ecological sustainability, which is defined as the long-term well-being of ecological systems, including human communities [176]. She stated that ecological sustainability should be the fundamental overarching principle that frames all other legal constructs in an ecological constitution and is much more specific than the idea of "sustainable development". The latter avoids critical terms like rights and responsibility and is highly ambiguous as a policy framework.

\subsection{A Nation Demanding an Ecological Constitution}

In 2016, a constitutional participation process took place in Chile, starting with small groups before moving on to provincial dialogues and, finally, regional discussions. In all these phases, environmental rights and responsibilities were among the most mentioned topics. Table 1 shows that the constitutional process (in which over 100,000 people partici-

pated) reached broad consensus on addressing environmental issues.

In Chile, demand for an ecological constitution has gained ground since the social uprising of 2019, but other countries had discussed the option previously, like Turkey in $2011[168,169]$. Chile's current constitutional process has prompted different initiatives in support of an ecological constitution. They include the Red de Constitucionalismo Ecológico (Ecological Constitutionalism Network), which has brought together over 50 academics and activists related to environmental issues, from topics such as pollution, environmental law, ecological conservation, human rights, and indigenous rights. They have focused on providing content for the new constitution in the context of a participation process through reports that promote biodiversity protection [173] and have, recently, published a book "Una Constitución Socioecológica para Chile: Propuestas Integradas" (A Socio-Ecological Constitution for Chile: Integrated Proposals) [177]. Another effort is the Recicla la Politica (Recycle Politics) initiative led by former ministers, undersecretaries, policymakers, activists, and academics.

In this context, we carried out a national survey in collaboration with IPSOS Chile, between 29 April and 6 May $2021(n=800)$ to ask people, over 18 years old, two questions related to an ecological constitution. In the survey, $79 \%$ of respondents agreed with the phrase: "An ecological focus is needed in the new constitution", with only $6 \%$ disagreeing and 15\% neither agreeing nor disagreeing. Similarly, 54\% agreed with the phrase: 
"A candidate's commitment to a green constitution is relevant for my decision to vote for a constitutional representative", with only $14 \%$ disagreeing.

Table 1. Most mentioned values and principles, rights, and responsibilities during the 2016 Constitutional Participation Process. Mentions (M) (in \%) indicate the proportion of participants agreeing to include a topic in the constitution. Social-environmental topics are in bold.

\begin{tabular}{|c|c|c|c|c|c|c|}
\hline $\begin{array}{l}\text { Priority } \\
\text { List }\end{array}$ & Values and Principles & $\begin{array}{l}M^{*} \\
(\%)\end{array}$ & Constitutional Rights & $\begin{array}{l}M^{*} \\
(\%)\end{array}$ & Constitutional Responsibilities & $\begin{array}{l}M^{*} \\
(\%)\end{array}$ \\
\hline 1 & Democracy & 99.2 & Health & 95.9 & Protection and conservation of nature & 100 \\
\hline 2 & Equality & 97.1 & Social security & 93.7 & Respect for the constitution & 95.1 \\
\hline 3 & $\begin{array}{l}\text { Decentralized } \\
\text { government }\end{array}$ & 97.3 & Education & 93.1 & $\begin{array}{l}\text { Protection and conservation of } \\
\text { historical and cultural heritage }\end{array}$ & 94.7 \\
\hline 4 & Justice & 95.7 & Dignified housing & 92.1 & Respect for the rights of others & 94.5 \\
\hline 5 & $\begin{array}{c}\text { Conservation of nature } \\
\text { or environment }\end{array}$ & 83.9 & Equality before the law & 90.8 & Enforcement of laws and regulations & 94.3 \\
\hline 6 & Respect & 79.2 & $\begin{array}{l}\text { Respect for nature and } \\
\text { the environment }\end{array}$ & 87.0 & $\begin{array}{l}\text { Protection and promotion of } \\
\text { fundamental human rights }\end{array}$ & 93.1 \\
\hline 7 & $\begin{array}{l}\text { Common good, } \\
\text { community }\end{array}$ & 8.0 & Life & 86.4 & $\begin{array}{c}\text { Legitimate and non-abusive exercise } \\
\text { of rights }\end{array}$ & 87.0 \\
\hline
\end{tabular}

The survey's results are consistent with those of the election of delegates to the constitutional convention, held in May 2021. Ecological priorities were evident in the programs submitted by 105 of the 155 elected delegates [7]. These programs included the constitutional right to access water, protect biodiversity, address climate change, and live in a healthy environment as well as the right to public participation and the recognition of indigenous peoples. This indicates that the long-standing inclination of Chileans in favor of environmental protection has resulted in a constitutional convention in which most delegates support the drafting of an ecological constitution.

The broad representation of different organizations, ideologies, and cultural backgrounds in the constitutional convention is noteworthy. It comprises 37 representatives from right-wing parties, 53 from left-wing parties, and 65 independents. Among the independents, 15 belong to indigenous peoples and a Mapuche was, moreover, elected as the president of the convention, which started work in June $2021[178,179]$. The convention is also the first in the world with gender parity [180].

\section{Recommendations for an Ecological Constitution to Achieve Social- Environmental Justice}

Based on our analysis, we suggest the inclusion of territorial rights in the new constitution as a crucial principle for achieving social-environmental justice in Chile. These territorial rights should be understood as recognition of the country's heterogeneous ecosystems and cultural heritage as well as the possibility of local jurisdiction for socialenvironmental issues according to each territorial context. Territorial rights differ slightly from nature or environmental rights, which are the principles most advocated by part of civil society. Nature rights protect the environment for its intrinsic value, rather than based on cost-benefit analysis. However, territorial heterogeneity would make it difficult to apply nature or environmental rights homogenously across the national territory.

For example, water management cannot be the same in northern Chile (with a potential water availability of less than $500 \mathrm{~m}^{3} /$ person/year) as in southern Chile (with a potential water availability of some $30,000 \mathrm{~m}^{3} /$ person/year) [181]. Heterogeneity is also present in the climate, soils, biodiversity, and cultural backgrounds [182,183]. Moreover, considering that industries in Chile are very dependent on natural resources, a general restriction on these resources could have a drastic effect on the economy. In contrast, management of 
the use of these resources in such a way as to avoid major impacts on natural heritage and promote good social-environmental practices would bring increased public benefits for the country. In 2008, Ecuador became the first country to include rights of nature in its constitution [184], but it still maintains a development based on the exploitation of natural resources [185]. We can envision a similar outcome in Chile if it simply adopts the rights of nature. Instead, we consider that a holistic perspective focusing on heterogeneous territories, including their components, structures, and the linkages among them, would be the most appropriate approach through which to address social-environmental issues.

Territorial rights differ from property rights, although both are forms of ownership rights. Property rights refer to land ownership while territorial rights refer to the right to make laws concerning the ownership of real estate [186]. As a result, territorial rights can pay attention to environmental concerns and resource rights $[187,188]$ while property owners act freely as to land use, but considering the ecosystem's limitations [186]. As mentioned in Section 3.1, property rights can take priority over environmental protection under the current constitution. In this sense, including territorial rights in the new constitution is in line with the recent analysis of Bauer et al. [155]. They suggest that decision-making bodies should no longer be able to ignore an action's effects on an ecosystem. That is, decisions should no longer focus solely on the protection of the private property rights of a person who wants to undertake an activity or may be affected by environmental regulation, but also on how the exercise of those rights may affect the environment. Therefore, we argue that territorial rights should be enshrined in the new constitution, rather than only in a law, since they should not have be lower in the hierarchy than property rights.

We argue that the new Chilean constitution should consider the country's ecosystems in territorial stewardship [188] to protect the environment, biodiversity, and ecological functions. The environment is linked to society's welfare due to its importance as a natural resource, but biodiversity is often underemphasized. Biodiversity loss has critical implications for humanity, from the collapse of food availability and health systems to the disruption of entire supply chains $[189,190]$. The current development model has proved economically inefficient because it has compromised the future supply of national resources [189]. Therefore, biodiversity loss is no longer a purely environmental issue, but an economic problem since ecosystem services are equivalent to 1.8 times global GNP $[189,191]$. Indeed, in 2018, the World Economic Forum (WEF) identified biodiversity loss as one of the top five risks for the economy [190]. Thus, we advocate a long-term perspective in the new constitution under which economic development is not at the expense of ecosystems, but rather recognizes dependence on them.

We also argued that a territorial approach is needed to protect invaluable heritage in the territory. The link between people and land is a crucial feature of national identity. However, the quantification of land values merely in terms of individual real estate does not accord these interests in any respect at all (Michael Walzer in [186]). According to Miller [192], peoples gain such rights by adding material value to the territory in question and endowing it with symbolic value. Considering that territory is a space with a socially constructed identity and that those territories are co-produced through discourses and practices that provisionally stabilize particular material and immaterial characteristics of specific places and populations $[193,194]$, territorial rights can empower communities in two dimensions: space by granting the demand for the use, enjoyment, and management of natural resources, and processes with control over political, economic, social, and cultural processes for ensuring reproduction and the material and cultural continuity of the group so that they are completed within the normative traditions of indigenous peoples [195].

To make a real contribution to both the environment and society, we suggest establishing territorial rights through land planning. Currently, land planning in Chile has several weaknesses [196]. Briefly, it is still very centralized and based on administrative boundaries, instead of geographical ones. Accordingly, we suggest that the new constitution should consider an institutional framework that fulfills the role of land planning based on watershed boundaries. Watershed boundaries promote a geographical perspective 
from mountains to oceans, which was part of the national culture until the beginning of the 19th century. However, the development of rail transport then reduced the importance of these boundaries and increased dependence on Santiago and the country's centralization [197]. Watershed management is a holistic approach that usually provides the most technically sound and economically efficient means of addressing water issues and incorporates a full range of other resource management activities [198].

According to a national report, there are 129 watersheds in the Chilean territory (Figure 3a) [199]. In line with our previous arguments, we proposed integrating these watersheds according to the corresponding ecosystems to group areas that could be managed similarly (Figure 3b). Thus, a potential framework would be the establishment of five macro-regions limited by hydrological boundaries and the predominant ecosystems: Northern Chile with the Atacama Desert and Andean Altiplano ecoregions; Northern Central Chile with the Atacama Desert and Andean Steppe ecoregions; Central Chile with Matorral and Sclerophyllous Forest and Andean Steppe ecoregions; Southern Central with the Valdivian Forest ecoregion; and Austral Southern with the Sub-Antarctic Forest ecoregion, Southern Patagonian Ice Field, and Andean Steppe ecoregions. Thus, although each watershed will have its own specific needs, they could act coordinately in each macroregion. We remark that some watersheds have two or three ecoregions inside their limits, and that every ecoregion entails several ecosystems. This scenario is currently a problem once the most productive ecoregions or ecosystems are protected (e.g., for agricultural activities) at the cost of others. However, different ecosystems in a same watershed are linked, and the impacts on one ecosystem will affect the others. In contrast, the proposed watershed management should respect this landscape by understanding the interdependence of the ecosystems.

We envision that land planning would help to achieve balanced socioeconomic development of Chile's regions, responsible management of natural resources, environmental justice, and an improvement in the well-being of the regions' inhabitants. To reach these goals, a land planning institutional framework should establish national baselines for different natural resources and cultural heritage. Once it is established, it should holistically carry out land planning, that is, integrating the different baselines. This is in contrast to the current structure. Chile has three specialized environmental courts, with geographical jurisdiction over the north, center, and south of the country. They can order the reparation of environmental damage and annul illegal administrative acts. 


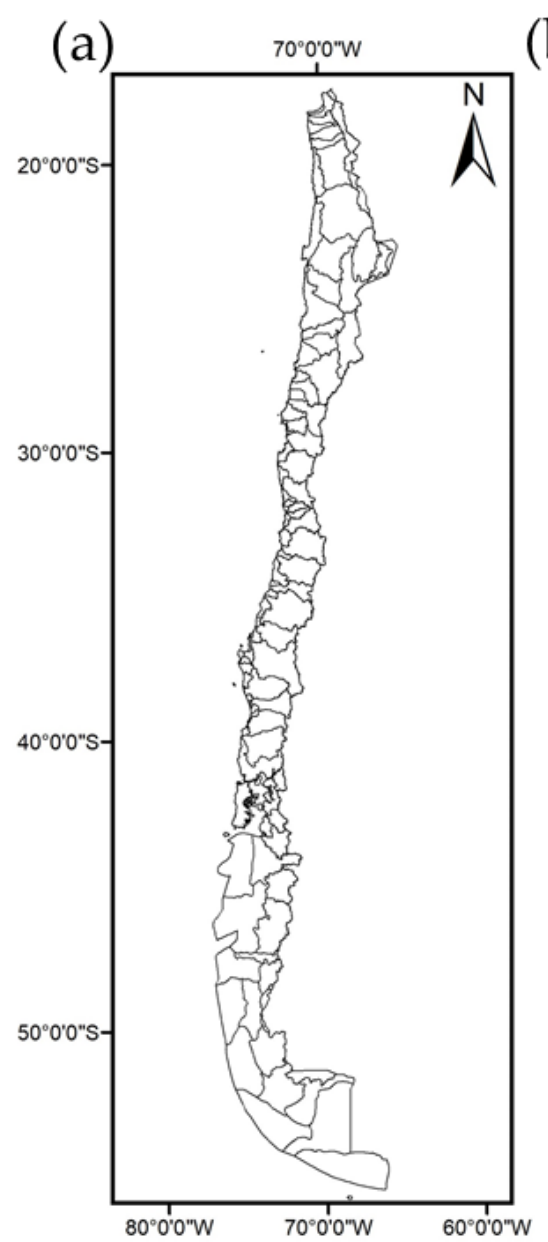

(b)
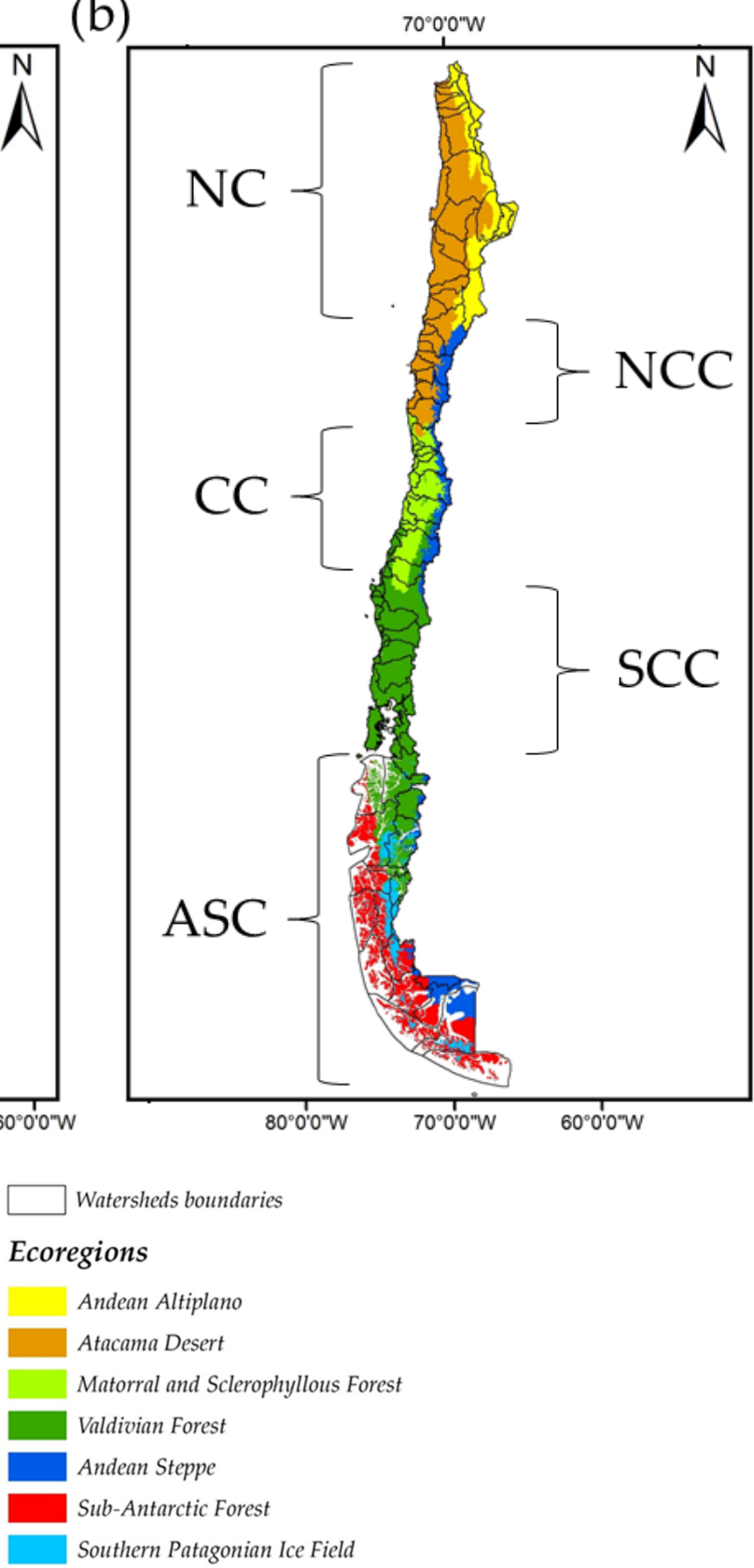

Figure 3. A potential land planning based on watershed boundaries. (a) Watershed boundaries in the national territory according to national reports $[199,200]$. (b) Map of Chile integrating watersheds within ecoregions (ecoregions adapted from [201]). Through this integration, five similar macroregions are discerned: $\mathrm{NC}=$ Northern Chile; $\mathrm{NCC}=$ Northern Central Chile; $\mathrm{CC}=$ Central Chile; SCC $=$ Southern Central Chile; and ASC $=$ Austral Southern Central Chile

However, sector-specific regulation (for example, of terrestrial or maritime waters, forests, coastal areas, etc.) is considered outside their jurisdiction. Moreover, the ability of the most vulnerable groups to access these courts is limited due to the high legal costs involved [155]. While we recommend a decentralization process, we do not advocate total regional autonomy such as eco-federalism. Eco-federalism promotes decision-making within an ecological democracy, but also involves many dangers inherent to the total dismantling of all centralizing structures [202]. Thus, we consider that Chile needs an institutional framework binding on the needs of industries, inhabitants, and ecosystems, with democratically chosen representatives, with greater autonomy and accountability. 
The land planning institutional framework could also contribute to national strategies or commitments through regional goals based on the ecosystem's carrying capacity [203]. For example, the Chilean government has made a global commitment to the reforestation of 500,000 hectares, mainly with native species, by 2030 [204]. We believe that a land planning institutional framework would permit achievement of this goal by promoting the ecological restoration of forests. This differs from a single national perspective under which all forest cover is concentrated in the south of the country as discussed in Section 2.6.1. We also note that ecological restoration through land planning would enhance the social-environmental benefits of the restored ecosystem. Specifically, it would promote the connection of habitats in contrast to the current situation in which ecological restoration efforts are fragmented because they depend on the will of the property owner. In addition, a land planning institutional framework could promote fulfillment of the Sustainable Development Goals Agenda (United Nations) and other international commitments equitably in the national territory.

We think the territorial rights as a principle in the constitution could be the basis for implementing new policies that promote sustainable development and environmental justice in Chile, by balancing people's needs with environmental and ecological boundaries. We argue that this approach would avoid or mitigate social-environmental conflicts analyzed in this review. For example, water disputes in Petorca could be regulated by assuring the availability to urban consumption while promoting water reuse, soil conservation, and improving water efficiency. In Puchuncaví valley, land planning could regulate the companies allowed based on job opportunities and environmental externalities. Additionally, it could promote environmental remediation considering the protection of human health and ecosystem functioning. Finally, in the case of Chiloé, the ecosystem carrying capacity concept should be considered in the allowed load of production. This would allow preventive action instead of reactive. In these three cases, land planning could keep companies functioning but respecting environmental boundaries and promoting good practices according to present and future challenges.

Territorial rights offer communities an essential remedy and mechanism for recognition, procedural justice, and distributive justice. For example, territorial rights will guarantee that (i) local and Indigenous communities are consulted before any prospecting or exploitation, (ii) studies, including both scientific and indigenous epistemologies, are conducted on the effects of any potential project in their lands, (iii) communities' benefit from the profits of exploitation and use, and (iv) communities are compensated for any damage caused by projects occurring in their territories. In this sense, we think land planning based on watershed boundaries and including cultural heritage could face problems as those of Lican Antai, Quechua, and Aymara indigenous communities, reviewed in Section 2.3.2. For example, in New Zealand, a river was granted legal personality because of its ancestral relationship with indigenous peoples. This legislation has helped to promote the rights of indigenous peoples whilst also fostering the long-term protection of natural and cultural heritage [205].

On the other hand, land planning would remediate the excessive centralization in the country. Historically, Chile's state has promoted large conservation areas in southern but is very scarce in the northern. That is, protecting Austral forests is preferred over arid ecosystems under the centralized governance perspective. However, northern ecosystems have also high natural and cultural values that people therein want to protect.

Behind the principle of territorial rights, there is also territorial equity, which would lead to social equity by providing all citizens with opportunities for access to resources and basic services so they can all develop their potential, regardless of the territory in which they reside. The importance of territorial rights must be understood, taking into account the social and environmental function of specific territories through identification of the value emanating from the common good and its conservation and protection to delimit property rights. Therefore, the new constitution should be within the earth stewardship framework in order to enhance ecosystem resilience and human well-being, which includes peoples' concerns about the aesthetic, cultural, and spiritual dimensions of valued places [175], thus 
ensuring harmonious and equitable development that creates rules considering territorial contexts and respects cultures, vocations, and the territory's social structure. Finally, we urge the convention's delegates to consider this review and its recommendations for discussion with the common goal of achieving environmental justice and making the new Chilean constitution a global model.

\section{Conclusions}

We have concluded that social-environmental conflicts are inextricably linked to Chile's current constitution, being one of the main reasons the property rights over land and water without considering the common good. These property rights have led to an abysmal inequity, and they are conditioning the development of future generations. Other problems associated with the current constitution may be the absence of regulatory frameworks (such as land planning) and the non-inclusion of nation heritage frameworks. However, constitutional issues are not the only component since some conflicts can be attributed mainly to weak regulation and/or the excessive centralization in the country administration and the revenue distribution.

The results of a survey and the election of delegates to the constitutional convention indicate that environmental protection is one of the key demands of Chilean citizens. In this context, the challenge of drafting an ecological constitution is to ensure the development of current and future generations while including the notion of ecosystems not purely as an environmental issue, but also as one intrinsically connected with society and economic sectors.

We suggest the inclusion of territorial rights in the new constitution as a crucial principle for achieving social-environmental justice in Chile. Furthermore, we suggest establishing the territorial rights by land planning based on watershed boundaries. We envision that land planning would help achieve a balanced socio-economic development of Chilean regions, responsible management of natural resources, environmental justice, and an improvement in the wellbeing of their inhabitants.

Territorial rights as a principle in the constitution could be the basis of implementing new policies that promote sustainable development and environmental justice in Chile by balancing people's needs with environmental and ecological boundaries. Consequently, we think that the reviewed social-environmental conflicts would be avoided or mitigated through this territorial approach. For these reasons, we suggest the consideration of territorial rights to improve social-environmental conditions appropriate to territorial contexts instead of generic laws and norms which can work for other nations but not in a territorially heterogeneous country such as Chile.

Supplementary Materials: The following are available online at https: / www.mdpi.com/article/ 10.3390 / su132212701/s1, Supplementary Material Table S1: Environmental components included in international constitutions.

Author Contributions: Conceptualization, M.B., P.M. and P.D.-S.; Methodology, M.B., P.M. and P.D.-S.; Investigation, M.B., P.M., P.D.-S., P.R.-D., M.M.-C. and J.L.C.-D.; writing-original draft preparation, M.B., P.M., P.D.-S., P.R.-D. and J.L.C.-D.; writing-review and editing, M.B., P.M., P.D.-S., M.M.-C., J.L.C.-D. and J.T.I. All authors have read and agreed to the published version of the manuscript.

Funding: P.M. was funded by the ANID doctoral scholarship grant $\mathrm{N}^{\circ} 21201569$. P.R.-D. was funded by the ANID doctoral scholarship grant $N^{\circ}$ 21212396. P.D.-S. was funded by ANID/REGIONAL/ CERES/R19A1002. P.M., J.L.C.-D. and P.D.-S. were funded by ANID/PIA/ACT192027. J.L.C.-D. was funded by ANID/ECOS180008. J.T.I. was funded by ANID/Redes190033, ANID/FONDAP/15110006, ANID PIA/BASAL FB0002, and ANID/Fondecyt Regular 1200291. J.L.C.-D. is Associated Researcher of the Instituto de Ecología y Biodiversidad (IEB-Chile) funded by ANID ACE210006. J.L.C.-D. was funded by PUCV 039.431/2020 "Núcleo de Soluciones de base Natural", and M.M.-C. was funded by ESR UCV2095 (Centro de Acción Climática PUCV).

Institutional Review Board Statement: Not applicable. 
Informed Consent Statement: Not applicable.

Data Availability Statement: Not applicable.

Acknowledgments: The authors acknowledge the collaboration of IPSOS Chile for its contribution.

Conflicts of Interest: The authors declare no conflict of interest. The funders had no role in the design of the study; in the collection, analyzes, or interpretation of data; in the writing of the manuscript, or in the decision to publish the results.

\section{References}

1. Fawaz, M.; Scharifker, B.R.; Moraes, R.M.; Ibrahim, M.E.; Moradi, S.; Medina, E.; Maziak, W.; Sham, M.H.; Hidalgo, C.; Martinez Alier, J. Dispatches from a world in turmoil. Nature 2019, 576, 382-384. [CrossRef]

2. Bunyan, R. 18 killed as hundreds of thousands of protestors take to the streets in Chile. Here's what to know. TIME, 21 October 2019.

3. Garcés, M. October 2019: Social uprising in neoliberal Chile. J. Lat. Am. Cult. Stud. 2020, 28, 483-491. [CrossRef]

4. Caroca Soto, P.; Cartes, C.; Davies, T.P.; Olivari, J.; Rica, S.; Vogt-Geisse, K. The anatomy of the 2019 Chilean social unrest. Chaos 2020, 30, 073129. [CrossRef]

5. Organisation for Economic Co-Operation and Development (OECD). Material Productivity (Indicator). Available online: https:/ / data.oecd.org/materials/material-productivity.htm (accessed on 24 July 2021).

6. El Mostrador. El Apruebo Arrasó en las "Zonas de Sacrificio": Los Categóricos Porcentajes a Favor de la Nueva Constitución en Estas Comunas. 2020. Available online: https:/ / www.elmostrador.cl/dia/2020/10/27/el-apruebo-arraso-en-las-zonas-desacrificio-los-categoricos-porcentajes-a-favor-de-la-nueva-constitucion-en-estas-comunas/ (accessed on 14 November 2021).

7. Servicio Electoral de Chile. Información Electoral. Available online: www.servel.cl (accessed on 14 November 2021).

8. Obaid, C.A. "Democracia Ecológica": Lo Que Demandan las Organizaciones Medioambientales Para Una Nueva Constitución. Available online: https:/ /laboratorio.latercera.com/tiempo-de-actuar/noticia/democracia-ecologica-lo-demandan-lasorganizaciones-medioambientales-una-nueva-constitucion/890401/ (accessed on 14 November 2021).

9. Alonso, J. Chile: La crisis social también es medioambiental. DW, 29 October 2019.

10. Sowards, S.K. Environmental justice in international contexts: Understanding intersections for social justice in the twenty-first century. Environ. Commun. 2012, 6, 285-289. [CrossRef]

11. Belchior Rocha, H. Social work practices and the ecological sustainability of socially vulnerable communities. Sustainability 2018, 10, 1312. [CrossRef]

12. Rambaree, K.; Båld, M.; Backlund Rambaree, B. Worlds apart! Environmental injustices in Mauritius, Peru and Sweden. Int. Soc. Work 2020. [CrossRef]

13. Instituto Nacional de Derechos Humanos (INDH). Mapa de Conflictos Socioambientales en Chile. Available online: https:// mapaconflictos.indh.cl/\#/ (accessed on 14 December 2020).

14. Ministerio Secretaría General de la Presidencia. Constitución Política de la República de Chile; Ministerio Secretaría General de la Presidencia: Santiago, Chile, 1980.

15. Ministerio de Justicia. DFL 1122. Fija Texto del Código de Aguas; Ministerio de Justicia: Santiago, Chile, 1981.

16. Hadjigeorgalis, E. Las Reformas al Código de Aguas de 1981. Rev. Agr. For. UC 2002, 16, $18-21$.

17. Panez, A.; Roose, I.; Faúndez, R. Agribusiness facing its limits: The re-design of neoliberalization strategies in the exporting agriculture sector in Chile. Land 2020, 9, 66. [CrossRef]

18. Correa-Parra, J.; Vergara-Perucich, J.F.; Aguirre-Nuñez, C. Water privatization and inequality: Gini coefficient for water resources in Chile. Water 2020, 12, 3369. [CrossRef]

19. Ministerio de Obras Públicas (MOP). Mesa Nacional del Agua. Primer Reporte; Ministerio de Obras Públicas: Santiago, Chile, 2020.

20. Apey Guzman, A. La Fruticultura en Chile: Tendencias Productivas y su Expresión Territorial. Análisis Realizado a Partir de los Catastros Frutícolas Para el Período 1999-2018; ODEPA: Santiago, Chile, 2019.

21. Rivera, D.; Godoy-Faúndez, A.; Lillo, M.; Alvez, A.; Delgado, V.; Gonzalo-Martín, C.; Menasalvas, E.; Costumero, R.; GarcíaPedrero, Á. Legal disputes as a proxy for regional conflicts over water rights in Chile. J. Hydrol. 2016, 535, 36-45. [CrossRef]

22. Roose, I.; Panez, A. Social innovations as a response to dispossession: Community water management in view of socio-metabolic rift in Chile. Water 2020, 12, 566. [CrossRef]

23. Facchini, A.; Laville, S. Chilean villagers claim British appetite for avocados is draining region dry. Guardian 2018, 5, 2018.

24. Milne, N.; Moss, T. Is Our Love of Avocados Drying Chile's Water Supplies?; Thomson Reuters Foundation: London, UK, 2019.

25. IPCC. Climate Change 2014: Impacts, Adaptation, and Vulnerability. Part A: Global and Sectoral Aspects. Contribution of Working Group II to the Fifth Assessment Report of the Intergovernmental Panel on Climate Change; IPCC: Geneva, Switzerland, 2014.

26. Quintana, J.M.; Aceituno, P. Changes in the rainfall regime along the extratropical west coast of South America (Chile): $30-43^{\circ} \mathrm{S}$. Atmósfera 2012, 25, 1-22.

27. Garreaud, R.D.; Boisier, J.P.; Rondanelli, R.; Montecinos, A.; Sepúlveda, H.H.; Veloso-Aguila, D. The central Chile mega drought (2010-2018): A climate dynamics perspective. Int. J. Climatol. 2019, 40, 421-439. [CrossRef] 
28. Muñoz, A.A.; Klock-Barria, K.; Alvarez-Garreton, C.; Aguilera-Betti, I.; Gonzalez-Reyes, A.; Lastra, J.A.; Chavez, R.O.; Barria, P.; Christie, D.; Rojas-Badilla, M.; et al. Water crisis in Petorca basin, Chile: The combined effects of a mega-Drought and water Management. Water 2020, 12, 648. [CrossRef]

29. Oficina de Estudios y Politicas Agrarias (ODEPA); Centro de Información de Recursos Naturales (CIREN). Catastro Frutícola. Principales Resultados; ODEPA: Santiago, Chile, 2017.

30. Duran-Llacer, I.; Munizaga, J.; Arumi, J.L.; Ruybal, C.; Aguayo, M.; Saez-Carrillo, K.; Arriagada, L.; Rojas, O. Lessons to be learned: Groundwater depletion in Chile's Ligua and Petorca watersheds through an Interdisciplinary approach. Water 2020, 12, 2446. [CrossRef]

31. United Nations. Resolution 70/169. The Human Rights to Safe Drinking Water and Sanitation; United Nations: New York, NY, USA, 2016.

32. United Nations. Resolution 64/292. The Human Right to Water and Sanitation; United Nations: New York, NY, USA, 2010.

33. Gordillo, G.; Obed Mendez, J. Food Security and Sovereignty; Food and Agriculture Organization: Rome, Italy, 2013.

34. Garreaud, R.D.; Alvarez-Garreton, C.; Barichivich, J.; Boisier, J.P.; Christie, D.; Galleguillos, M.; LeQuesne, C.; McPhee, J.; Zambrano-Bigiarini, M. The 2010-2015 megadrought in central Chile: Impacts on regional hydroclimate and vegetation. Hydrol. Earth. Syst. Sci. 2017, 21, 6307-6327. [CrossRef]

35. Rojas, M.; Lambert, F.; Ramirez-Villegas, J.; Challinor, A.J. Emergence of robust precipitation changes across crop production areas in the 21st century. Proc. Natl. Acad. Sci. USA 2019, 116, 6673-6678. [CrossRef] [PubMed]

36. Ministerio de Agricultura. Ley 18.450. Aprueba Normas Para el Fomento de la Inversión Privada en Obras de Riego y Drenaje; Ministerio de Agricultura: Santiago, Chile, 1985.

37. Grafton, R.Q.; Williams, J.; Perry, C.J.; Molle, F.; Ringler, C.; Steduto, P.; Udall, B.; Wheeler, S.A.; Wang, Y.; Garrick, D.; et al. The paradox of irrigation efficiency. Science 2018, 361, 748-750. [CrossRef]

38. Baeza-Gomez, E. Proyecto de Reforma al Código de Aguas (Boletín N 7543-12). Available online: https:/ / obtienearchivo.bcn.cl/ obtienearchivo?id=repositorio/10221/26721/2/Informe_Codigo_de_Aguas.pdf (accessed on 14 November 2021).

39. Schulz, J.J.; Cayuela, L.; Echeverria, C.; Salas, J.; Rey Benayas, J.M. Monitoring land cover change of the dryland forest landscape of Central Chile (1975-2008). Appl. Geogr. 2010, 30, 436-447. [CrossRef]

40. Miranda, A.; Altamirano, A.; Cayuela, L.; Lara, A.; González, M. Native forest loss in the Chilean biodiversity hotspot: Revealing the evidence. Reg. Environ. Chang. 2016, 17, 285-297. [CrossRef]

41. Hernández, Á.; Arellano, E.C.; Morales-Moraga, D.; Miranda, M.D. Understanding the effect of three decades of land use change on soil quality and biomass productivity in a Mediterranean landscape in Chile. Catena 2016, 140, 195-204. [CrossRef]

42. Reyes, R.; Nelson, H. A tale of two forests: Why forests and forest conflicts are both growing in Chile. Int. For. Rev. 2014, 16, 379-388. [CrossRef]

43. Pimentel, D.; Burgess, M. Soil erosion threatens food production. Agriculture 2013, 3, 443. [CrossRef]

44. Pimentel, D.; Harvey, C.; Resosudarmo, P.; Sinclair, K.; Kurz, D.; McNair, M.; Crist, S.; Shpritz, L.; Fitton, L.; Saffouri, R.; et al. Environmental and economic costs of soil erosion and conservation benefits. Science 1995, 267, 1117-1123. [CrossRef]

45. Blaikie, P.; Jeanrenaud, S. Biodiversity and human welfare. In Revisiting Sustainable Development; UNRISD: Geneva, Switzerland, 1996.

46. Nkonya, E.; Anderson, W.; Kato, E.; Jawoo, K.; Mirzabaev, A.; von Braun, J.; Meyer, S. Global Cost of Land Degradation. In Economics of Land Degradation and Improvement-A Global Assessment for Sustainable Development; Nkonya, E., Mirzabaev, A., von Braun, J., Eds.; Springer: Cham, Switzerland, 2015; pp. 117-165.

47. Centro de Información de Recursos Naturales (CIREN). Determinación de la Erosión Actual y Potencial de los Suelos de Chile; Centro de Información de Recursos Naturales: Santiago, Chile, 2010. [CrossRef]

48. Youlton, C.; Espejo, P.; Biggs, J.; Norambuena, M.; Cisternas, M.; Neaman, A.; Salgado, E. Quantification and control of runoff and soil erosion on avocado orchards on ridges along steep-hillslopes. Cienc. Investig. Agrar. 2010, 37, 113-123. [CrossRef]

49. Miranda, F. Erosión de Suelos y Crisis Hídrica: Las Sombras del Modelo Agroexportador del Palto; Fundación TERRAM: Santiago, Chile, 2018.

50. Heilmayr, R.; Echeverría, C.; Lambin, E.F. Impacts of Chilean forest subsidies on forest cover, carbon and biodiversity. Nat. Sustain. 2020, 3, 701-709. [CrossRef]

51. Mora-Motta, A.; Stellmacher, T.; Habert, G.P.; Zúñiga, C.H. Between extractivism and conservation: Tree plantations, forest reserves, and peasant territorialities in Los Ríos, Chile. In Ecological Economic and Socio Ecological Strategies for Forest Conservation; Fuders, F., Donoso, P., Eds.; Springer: Cham, Switzerland, 2020. [CrossRef]

52. Soto Aguirre, D.; Gysling Caselli, J.; Kahler González, C.; Álvarez Gonzalez, V.; Poblete Hernández, P.; Pardo Velásquez, E. Chilean Statistical Yearbook of Forestry 2020; Instituto Forestal: Santiago, Chile, 2020.

53. Manuschevich, D. Neoliberalization of forestry discourses in Chile. For. Policy. Econ. 2016, 69, 21-30. [CrossRef]

54. Carranza, D.M.; Varas-Belemmi, K.; De Veer, D.; Iglesias-Müller, C.; Coral-Santacruz, D.; Méndez, F.A.; Torres-Lagos, E.; Squeo, F.A.; Gaymer, C.F. Socio-environmental conflicts: An underestimated threat to biodiversity conservation in Chile. Environ. Sci. Policy 2020, 110, 46-59. [CrossRef]

55. Huber, A.; Iroumé, A.; Bathurst, J. Effect of Pinus radiata plantations on water balance in Chile. Hydrol. Process 2008, 22, 142-148. [CrossRef]

56. Soto, L.; Galleguillos, M.; Seguel, O.; Sotomayor, B.; Lara, A. Assessment of soil physical properties' statuses under different land covers within a landscape dominated by exotic industrial tree plantations in south-central Chile. J. Soil Water Conserv. 2018, 74, 12-23. [CrossRef] 
57. Torres-Salinas, R.; García, G.A.; Henríquez, N.C.; Zambrano-Bigiarini, M.; Costa, T.; Bolin, B.O.B. Forestry development, water scarcity, and the Mapuche protest for environmental justice in Chile. Ambient. Soc. 2016, 19, 121-144. [CrossRef]

58. Gómez-González, S.; Ojeda, F.; Fernandes, P.M. Portugal and Chile: Longing for sustainable forestry while rising from the ashes. Environ. Sci. Policy 2018, 81, 104-107. [CrossRef]

59. González-Hidalgo, M.; Zografos, C. How sovereignty claims and "negative" emotions influence the process of subject-making: Evidence from a case of conflict over tree plantations from Southern Chile. Geoforum 2017, 78, 61-73. [CrossRef]

60. Wakatsuki, T.; Rasyidin, A. Rates of weathering and soil formation. Geoderma 1992, 52, 251-263. [CrossRef]

61. Comisión Chilena del Cobre (COCHILCO). Yearbook: Copper and Other Mineral Statistics 2000-2019; Comisión Chilena del Cobre: Santiago, Chile, 2020.

62. Index Mundi. Copper Production by Country (Metric Tons). Available online: https://www.indexmundi.com/minerals/ ?product $=$ copper\&graph $=$ production (accessed on 16 December 2020).

63. Adriano, D.C. Trace Elements in Terrestrial Environments, 2nd ed.; Springer: New York, NY, USA, 2001; p. 867. [CrossRef]

64. Baeza, A.; Pérez, M.E. Contaminación con Azufre en Escuela La Greda Deja 31 Niños Intoxicados. Available online: https://www. latercera.com/noticia/contaminacion-con-azufre-en-escuela-la-greda-deja-31-ninos-intoxicados/ (accessed on 4 November 2021).

65. González, I.; Neaman, A.; Rubio, P.; Cortés, A. Spatial distribution of copper and pH in soils affected by intensive industrial activities in Puchuncaví and Quintero, central Chile. J. Soil Sci. Plant Nutr. 2014, 14, 943-953. [CrossRef]

66. Berasaluce, M.; Mondaca, P.; Schuhmacher, M.; Bravo, M.; Sauvé, S.; Navarro-Villarroel, C.; Dovletyarova, E.A.; Neaman, A. Soil and indoor dust as environmental media of human exposure to $\mathrm{As}, \mathrm{Cd}, \mathrm{Cu}$, and $\mathrm{Pb}$ near a copper smelter in central $\mathrm{Chile}$. J. Trace Elem. Med. Biol. 2019, 54, 156-162. [CrossRef]

67. United States (US) Environmental Protection Agency (EPA). Process for conducting probabilistic risk assessment. In Risk Assessment Guidance for Superfund: Volume III (Part A); US EPA: Washington, DC, USA, 2001.

68. Alekseev, I.; Neaman, A.; Lizardi, N.; Mondaca, P.; Aguilar, M. Assessment of potential health risk due to consumption of vegetables grown near a copper smelter in central Chile. Taurida Herald Agrar. Sci. 2018, 2, 9-14. [CrossRef]

69. Centro de Ecologia Aplicada (CEA). Análisis de Riesgo Ecológico por Sustancias Potencialmente Contaminantes en el Aire, Suelos y Agua, en las Comunas de Concón, Quintero y Puchuncaví; CEA: Santiago, Chile, 2013.

70. Ministerio de Salud (MINSAL). Reglamento Sanitario de Los Alimentos; MINSAL: Santiago, Chile, 1997.

71. Ministerio de Agricultura. Decreto 346. Declara Zona Saturada por Anhidrido Sulfuroso y Material Particulado al Área Circundante al Complejo Industrial Ventanas, V Región; Ministerio de Agricultura: Santiago, Chile, 1994.

72. Ministerio del Medio Ambiente (MMA). Decreto 10. Declara Zona Saturada por Material Particulado Fino Respirable MP2,5, Como Concentración Anual y Latente Como Concentración Diaria, y Zona Latente por Material Particulado Respirable MP10, Como Concentración Anual, a las Comunas de Concón, Quintero y Puchuncaví; Ministerio del Medio Ambiente: Santiago, Chile, 2015.

73. Ginocchio, R. Effects of a copper smelter on a grassland community in the Puchuncaví Valley, Chile. Chemosphere 2000, 41, 15-23. [CrossRef]

74. Pardo, J.; Mondaca, P.; Celis-Diez, J.L.; Ginocchio, R.; Navarro-Villarroel, C.; Neaman, A. Assessment of revegetation of an acidic metal(loid)-polluted soils six years after the incorporation of lime with and without compost. Geoderma 2018, 331, 81-86. [CrossRef]

75. Badal Thomas, L. Valoración de Pérdidas Económicas Generadas por la Degradación de las Tierras. Valle de Puchuncaví, Región de Valparaíso, Chile; Universidad de Chile: Santiago, Chile, 2014.

76. Folchi, M. Las grandes fundiciones y la contaminación atmosférica: Chagres y Ventanas, 1959-2006. In Historia Ambiental de las Labores de Beneficio en la Minería del Cobre en Chile, Siglox XIX y XX; Folchi, M., Ed.; Universitat de Barcelona: Barcelona, Spain, 2006.

77. Malman, S.; Sabatini, F.; Geisse, G.G. El trasfondo socioeconómico del conflicto ambiental de Puchuncaví. Amb. Desarro. 1995, $X I, 49-58$.

78. International Energy Agency (IEA). Global EV Outlook 2020; IEA: Paris, France, 2020. Available online: https://www.iea.org/ reports/global-ev-outlook-2020 (accessed on 9 November 2021).

79. Evarts, E.C. Lithium batteries: To the limits of lithium. Nature 2015, 526, S93-S95. [CrossRef]

80. United States Geological Survey (USGS). Lithium Statistics and Information. Available online: https://www.usgs.gov/centers/ nmic/lithium-statistics-and-information (accessed on 22 December 2020).

81. Romero, H.; Méndez, M.; Smith, P. Mining development and environmental injustice in the Atacama desert of northern Chile. Environ. Justice 2012, 5, 70-76. [CrossRef]

82. Romero-Toledo, H. Extractivismo en Chile: La producción del territorio minero y las luchas del pueblo aimara en el Norte Grande. Colombia Int. 2019, 3-30. [CrossRef]

83. Santoro, C.M.; Castro, V.; Capriles, J.M.; Barraza, J.; Correa, J.; Marquet, P.A.; McRostie, V.; Gayo, E.M.; Latorre, C.; Valenzuela, D.; et al. Acta de Tarapacá: "Pueblo sin agua, pueblo muerto". Chungará (Arica) 2018, 50, 169-174. [CrossRef]

84. Whyte, K.P. The Recognition Dimensions of Environmental Justice in Indian Country. SSRN J. 2011, 4, 199-205. [CrossRef]

85. Molina Camacho, F. Intergenerational dynamics and local development: Mining and the indigenous community in Chiu Chiu, El Loa Province, northern Chile. Geoforum 2016, 75, 115-124. [CrossRef]

86. Babidge, S. Contested value and an ethics of resources: Water, mining and indigenous people in the Atacama Desert, Chile. Aust. J. Anthropol. 2016, 27, 84-103. [CrossRef] 
87. Babidge, S.; Bolados, P. Neoextractivism and indigenous water ritual in Salar de Atacama, Chile. Lat. Am. Perspect. 2018, 45, 170-185. [CrossRef]

88. McGregor, D.; Whitaker, S.; Sritharan, M. Indigenous Environmental Justice and Sustainability. Curr. Opin. Environ. Sustain. 2020, 43, 35-40. [CrossRef]

89. Bull, A.T.; Asenjo, J.A. Microbiology of hyper-arid environments: Recent insights from the Atacama Desert, Chile. Antonie Leeuwenhoek 2013, 103, 1173-1179. [CrossRef] [PubMed]

90. Cubillos, C.F.; Aguilar, P.; Grágeda, M.; Dorador, C. Microbial communities from the world's largest lithium reserve, Salar de Atacama, Chile: Life at high LiCl Concentrations. J. Geophys. Res. Biogeosci. 2018, 123, 3668-3681. [CrossRef]

91. Gajardo, G.; Redón, S. Andean hypersaline lakes in the Atacama Desert, northern Chile: Between lithium exploitation and unique biodiversity conservation. Cons. Sci. Prac. 2019, 1, e94. [CrossRef]

92. Liu, W.; Agusdinata, D.B.; Myint, S.W. Spatiotemporal patterns of lithium mining and environmental degradation in the Atacama Salt Flat, Chile. Int. J. Appl. Earth Obs. Geoinf. 2019, 80, 145-156. [CrossRef]

93. Dorador, C.; Fink, P.; Hengst, M.; Icaza, G.; Villalobos, A.S.; Vejar, D.; Meneses, D.; Zadjelovic, V.; Burmann, L.; Moelzner, J.; et al. Microbial community composition and trophic role along a marked salinity gradient in Laguna Puilar, Salar de Atacama, Chile. Antonie Leeuwenhoek 2018, 111, 1361-1374. [CrossRef] [PubMed]

94. Oberschelp, C.; Pfister, S.; Raptis, C.E.; Hellweg, S. Global emission hotspots of coal power generation. Nat. Sustain. 2019, 2, 113-121. [CrossRef]

95. Ministerio del Medio Ambiente. Gobierno Anuncia Salida de 8 Centrales a Carbón en 5 Años y Retiro Total al 2040. Available online: https:/ / mma.gob.cl/gobierno-anuncia-la-salida-de-8-centrales-a-carbon-en-5-anos-y-la-meta-de-retiro-total-al-2040 / (accessed on 14 November 2021).

96. Chile Sustentable. Matriz Eléctrica y Generación a Carbón en Chile. Propuestas Para Acelerar la Transición Energética. Available online: http:/ / www.chilesustentable.net/wp-content/uploads/2017/11/Cartilla-Termoelectricas-a-Carbon-Propuestas-ParaAcelerar-La-Transicion-Energetica-2017.pdf (accessed on 14 November 2021).

97. Cortés, S.; Viviani, P.; Ojeda, M.; Leiva, C. Informe Final: Daños en Salud Asociados a la Exposición a Centrales Termoeléctricas a Carbón en la Zona Norte de Chile: Análisis de Datos Secundarios; Pontificia Universidad Católica de Chile: Santiago, Chile, 2019.

98. Ruiz-Rudolph, P.; Arias, N.; Pardo, S.; Meyer, M.; Mesias, S.; Galleguillos, C.; Schiattino, I.; Gutierrez, L. Impact of large industrial emission sources on mortality and morbidity in Chile: A small-areas study. Environ. Int. 2016, 92-93, 130-138. [CrossRef] [PubMed]

99. Orellana, M.A. Indigenous peoples, energy and environmental justice: The Pangue/Ralco hydroelectric project in Chile's Alto BíoBío. J. Energy Nat. Resour. Law 2015, 23, 511-528. [CrossRef]

100. Zanotti, L. Water and life: Hydroelectric development and indigenous pathways to justice in the Brazilian Amazon. Polit. Groups Identities 2015, 3, 666-672. [CrossRef]

101. Tironi, M.; Sannazzaro, J. Energía huilliche. Experimentos en integración y disensos ontológicos en un parque eólico. Rev. Int. Sociol. 2017, 75, e080. [CrossRef]

102. El Mekaoui, A.; Tariq, R.; Ramírez, O.B.; Méndez-Monroy, P.E. Sustainability, sociocultural challenges, and new power of capitalism for renewable energy megaprojects in an indigenous mayan community of Mexico. Sustainability 2020, 12, 7432. [CrossRef]

103. Acuña, G.; Serrano, R. Los conflictos socio-ambientales energéticos en América Latina: A proposito de las energías renovables en la agenda 2030/UN. In Desarrollo Sostenible y Matriz Energética en América Latina; Caldeira Brant, L.N., Rodrigues, J.B., De Oliveira Biazatti, B., Soares Amaral, J., Feres Ragil, R.R., Avelar Freitas, D., Eds.; Konrad Adenauer Stiftung: Belo Horizonte, Brazil, 2016.

104. Susskind, L.; Kausel, T.; Aylwin, J.; Fierman, E. The future of hydropower in Chile. J. Energy Nat. Resour. Law 2015, 32, 425-481. [CrossRef]

105. González-Parra, C.; Simon, J. All that glitters is not gold. Am. Behav. Sci. 2008, 51, 1774-1789. [CrossRef]

106. Nesti, L. The Mapuche-Pehuenche and the Ralco Dam on the Biobío River: The challenge of protecting indigenous land rights. Int. J. Minor. Group Rights 2002, 9, 1-40. [CrossRef]

107. Mansilla Torres, S. Chiloé y los dilemas de su identidad cultural ante el modelo neoliberal chileno: La visión de los artistas e intelectuales. Alpha (Osorno) 2006, 23, 9-36. [CrossRef]

108. Pérez-Orellana, D.C.; Delgado, L.E.; Marin, V.H. The adaptive cycle and the ecosystem services: A social-ecological analysis of Chiloé Island, southern Chile. Ecol. Soc. 2020, 25, 34. [CrossRef]

109. Soto, D.; Jara, F.; Moreno, C. Escaped salmon in the inner seas, southern Chile: Facing ecological and social conflicts. Ecol. Appl. 2001, 11, 1750-1762. [CrossRef]

110. Vester, H.; Timme, M. Call for cooperation to contain damage by Chile's salmon farms. Nature 2010, 465, 869. [CrossRef]

111. Quiñones, R.A.; Fuentes, M.; Montes, R.M.; Soto, D.; León-Muñoz, J. Environmental issues in Chilean salmon farming: A review. Rev. Aquac. 2019, 11, 375-402. [CrossRef]

112. Barrionuevo, A. Salmon virus indicts Chile's fishing methods. The New York Times, 27 March 2008.

113. Asche, F.; Hansen, H.; Tveteras, R.; Tveteras, S. The salmon disease crisis in Chile. Mar. Resour. Econ. 2009, 24, 405-411. [CrossRef]

114. Aguayo, B.E.C.; Parra, J.M.B. Governances and invisibilities: Interests and rationalities in the socio-environmental regulation of salmon farming in Chile. Ambient. Soc. 2017, 20, 105-120. [CrossRef]

115. Niklitschek, E.J.; Soto, D.; Lafon, A.; Molinet, C.; Toledo, P. Southward expansion of the Chilean salmon industry in the Patagonian Fjords: Main environmental challenges. Rev. Aquac. 2013, 5, 172-195. [CrossRef]

116. Pinto, F.; Kremerman, M. Cultivando Pobreza: Condiciones Laborales en la Salmonicultura; Terram: Santiago, Chile, 2005. 
117. Franklin, J. Toxic 'red tide' in Chile prompts investigation of salmon farming. The Guardian, 17 May 2016.

118. Armijo, J.; Oerder, V.; Auger, P.A.; Bravo, A.; Molina, E. The 2016 red tide crisis in southern Chile: Possible influence of the mass oceanic dumping of dead salmons. Mar. Pollut. Bull. 2020, 150, 110603. [CrossRef] [PubMed]

119. Jiménez, V.; Hidalgo, R.; Campesino, A.-J.; Alvarado, V. Normalización del modelo neoliberal de expansión residencial más allá del límite urbano en Chile y España. EURE (Santiago) 2018, 44, 27-46. [CrossRef]

120. Garrido, E.; Valenzuela, G.; Misle, E.; Aravena, G. Cambios en la propiedad agrícola del sector reformado chileno en la comuna de Curicó (Chile), período 1975-2007. Espacios 2019, 40, 3-14.

121. Hidalgo, R.; Salazar, A.; Lazcano, R.; Roa, P.F.; Alvarez, C.L.; Calderón, M. Transformaciones socioterritoriales asociadas a proyectos residenciales de condominios en comunas de la periferia del área metropolitana de Santiago. Rev. Invi 2005, 20, 104-133.

122. Barton, J.R.; Ramírez, M.I. The role of planning policies in promoting urban sprawl in intermediate cities: Evidence from Chile. Sustainability 2019, 11, 7165. [CrossRef]

123. Naranjo Ramírez, G. Efectos de un instrumento de planificación en el periurbano de Santiago. Caso de Estudio: Comuna de Tiltil. Scr. Nova 2005, 9, 38 .

124. Hidalgo, R.; Borsdorf, A.; Plaza, F. Parcelas de agrado alrededor de Santiago y Valparaíso: ¿Migración por amenidad a la chilena? Rev. Geogr. Norte Gd. 2009, 44, 93-112. [CrossRef]

125. Gálvez, N.; Infante, J.; Fernandez, A.; Díaz, J.; Petracca, L. Land use intensification coupled with free-roaming dogs as potential defaunation drivers of mesocarnivores in agricultural landscapes. J. Appl. Ecol. 2021. [CrossRef]

126. World Wildlife Fund (WWF). Medio Ambiente y Protección de la Biodiversidad en las Constituciones del Mundo. Available online: https:/ / wwflac.awsassets.panda.org/downloads/wwfchile_analisisconstituciones.pdf (accessed on 14 November 2021).

127. Myers, N.; Mittermeier, R.A.; Mittermeier, C.G.; da Fonseca, G.A.; Kent, J. Biodiversity hotspots for conservation priorities. Nature 2000, 403, 853-858. [CrossRef] [PubMed]

128. Castañeda, L.E.; Godoy, K.; Manzano, M.; Marquet, P.A.; Barbosa, O. Comparison of soil microbial communities inhabiting vineyards and native sclerophyllous forests in central Chile. Ecol. Evol. 2015, 5, 3857-3868. [CrossRef] [PubMed]

129. Montoya-Tangarife, C.; de la Barrera, F.; Salazar, A.; Inostroza, L. Monitoring the effects of land cover change on the supply of ecosystem services in an urban region: A study of Santiago-Valparaiso, Chile. PLoS ONE 2017, 12, e0188117. [CrossRef] [PubMed]

130. Choi, D.-A.; Park, K.; Rigolon, A. From XS to XL urban nature: Examining access to different types of green space using a 'just sustainabilities' framework. Sustainability 2020, 12, 6998. [CrossRef]

131. Corporación Nacional Forestal (CONAF). Listado Sistema Nacional de Áreas Silvestres Protegidas del Estado (SNASPE); CONAF: Santiago, Chile, 2020.

132. INE. Sintesis de Resultados Censo. 2017. Available online: https://www.censo2017.cl/descargas/home/sintesis-de-resultadoscenso2017.pdf (accessed on 14 November 2021).

133. Corporación Nacional Forestal (CONAF). Evaluación de la Percepción de los Visitantes Respecto de la Calidad del Servicio Ofrecido en las Áreas Silvestres Protegidas del Estado 2016; CONAF: Santiago, Chile, 2016.

134. Roman, B.; Nahuelhual, L. Áreas protegidas públicas y privadas en el sur de Chile. Caracterización del perfil de sus visitantes. Estud. Perspect. Tur. 2009, 18, 490-507.

135. Opazo Urrutia, L.E. Uso Recreativo en el Sistema Nacional de Áreas Silvestres Protegidas del Estado y su Relación con los Cambios Socioeconómicos en Chile, en el Período 1986 a 2000; Universidad de Concepción: Concepción, Chile, 2004.

136. Perry Otárola, A.I. Caracterización de los Visitantes del Parque Nacional Llanos de Challe, Región de Atacama; Universidad de Chile: Santiago, Chile, 2017.

137. Hartig, T.; Evans, G.W.; Jamner, L.D.; Davis, D.S.; Gärling, T. Tracking restoration in natural and urban field settings. J. Environ. Psychol. 2003, 23, 109-123. [CrossRef]

138. Hanski, I.; von Hertzen, L.; Fyhrquist, N.; Koskinen, K.; Torppa, K.; Laatikainen, T.; Karisola, P.; Auvinen, P.; Paulin, L.; Makela, M.J.; et al. Environmental biodiversity, human microbiota, and allergy are interrelated. Proc. Natl. Acad. Sci. USA 2012, 109, 8334-8339. [CrossRef]

139. Haahtela, T.; Holgate, S.; Pawankar, R.; Akdis, C.A.; Benjaponpitak, S.; Caraballo, L.; Demain, J.; Portnoy, J.; von Hertzen, L.; WAO Special Committee on Climate Change and Biodiversity. The biodiversity hypothesis and allergic disease: World allergy organization position statement. World Allergy Organ. J. 2013, 6, 3-20. [CrossRef]

140. Bernstein, A.S. Biological diversity and public health. Annu. Rev. Public Health 2014, 35, 153-167. [CrossRef] [PubMed]

141. Ministerio del Medio Ambiente (MMA). Estrategia Nacional de Biodiversidad. 2017-2030. Available online: https:/ / mma.gob. cl/wp-content/uploads/2018/03/Estrategia_Nac_Biodiv_2017_30.pdf (accessed on 14 November 2021).

142. United Nations Environment Programme (UNEP) Convention on Biological Diversity (CBD) Secretariat. Decision X/2. The Strategic Plan for Biodiversity 2011-2020 and the Aichi Biodiversity Targets; UNEP: Nairobi, Kenya, 2010.

143. Reyes-Päcke, S.; Figueroa-Aldunce, I.M. Distribución, superficie y accesibilidad de las áreas verdes en Santiago de Chile. EURE (Santiago) 2010, 36, 89-110. [CrossRef]

144. Fuller, R.A.; Irvine, K.N.; Devine-Wright, P.; Warren, P.H.; Gaston, K.J. Psychological benefits of greenspace increase with biodiversity. Biol. Lett. 2007, 3, 390-394. [CrossRef]

145. Dallimer, M.; Irvine, K.N.; Skinner, A.M.J.; Davies, Z.G.; Rouquette, J.R.; Maltby, L.L.; Warren, P.H.; Armsworth, P.R.; Gaston, K.J. Biodiversity and the feel-good factor: Understanding associations between self-reported human well-being and species richness. BioScience 2012, 62, 47-55. [CrossRef] 
146. Parra-Saldívar, A.; Abades, S.; Celis-Diez, J.L.; Gelcich, S. Exploring perceived well-being from urban parks: Insights from a megacity in Latin America. Sustainability 2020, 12, 7586. [CrossRef]

147. Ministerio del Medio Ambiente. Encuestas Nacionales del Medio Ambiente. Available online: https://mma.gob.cl/encuestasnacionales-del-medio-ambiente/ (accessed on 14 November 2021).

148. País Circular. Encuesta Nacional Ambiental: Casi el 40\% de los Chilenos Recicla y un 30\% Dice Preferir Productos con Menos Empaques. Available online: https://www.paiscircular.cl/ciudad/encuesta-nacional-ambiental-casi-el-40-de-los-chilenosrecicla-y-un-30-dice-preferir-productos-con-menos-empaques / (accessed on 14 November 2021).

149. Mena-Carrasco, M.; Saide, P.; Delgado, R.; Hernandez, P.; Spak, S.; Molina, L.; Carmichael, G.; Jiang, X. Regional climate feedbacks in Central Chile and their effect on air quality episodes and meteorology. Urban Clim. 2014, 10, 771-781. [CrossRef]

150. Ministerio del Medio Ambiente. Informe del Estado del Medio Ambiente 2020; Ministerio del Medio Ambiente: Santiago, Chile, 2020.

151. Rose-Perez, R. Environmental justice and air quality in Santiago de Chile. Rev. Salud Publica (Bogota) 2015, 17, 337-350. [CrossRef]

152. Fernández, I.C.; Wu, J. Assessing environmental inequalities in the city of Santiago (Chile) with a hierarchical multiscale approach. Appl. Geogr. 2016, 74, 160-169. [CrossRef]

153. Pino-Cortés, E.; Díaz-Robles, L.A.; Campos, V.; Vallejo, F.; Cubillos, F.; Gómez, J.; Cereceda-Balic, F.; Fu, J.; Carrasco, S.; Figueroa, J. Effect of socioeconomic status on the relationship between short-term exposure to PM2.5 and cardiorespiratory mortality and morbidity in a megacity: The case of Santiago de Chile. Air Qual. Atmos. Health 2020, 13, 509-517. [CrossRef]

154. Mohai, P.; Pellow, D.; Roberts, J.T. Environmental justice. Annu. Rev. Environ. Resour. 2009, 34, 405-430. [CrossRef]

155. Bauer, C.; Blumm, M.C.; Delgado, V.; Guiloff, M.; Hervé, D.; Jiménez, G.; Benson, R.; McKay, T.; Marshall, P. The Protection of Nature and a New Constitution for Chile: Lessons from the Public Trust Doctrine. SSRN Electron. J. 2021. [CrossRef]

156. Agostini, C.; Silva, C.; Nasirov, S. Failure of energy mega-projects in Chile: A critical review from sustainability perspectives. Sustainability 2017, 9, 1073. [CrossRef]

157. Mendoza, Y.; Loyola, R.; Aguilar, A.; Escalante, R. Valuation of air quality in Chile: The life satisfaction approach. Soc. Indic. Res. 2019, 145, 367-387. [CrossRef]

158. IPSOS. Earth Day 2020: How Does the World View Climate Change and COVID19; IPSOS: Paris, France, 2020.

159. Organisation for Economic Co-Operation and Development (OECD). Making Decentralisation Work in Chile: Towards Stronger Municipalities; OECD Publishing: Paris, France, 2017.

160. Brockhaus, M.; Kambire, H. Decentralization: A window of opportunity for successful adaptation to climate change. In Adapting to Climate Change: Thresholds, Values, Governance; Adger, N.W., Lorenzoni, I., O’Brien, K.L., Eds.; Cambridge University Press: Cambridge, UK, 2009; pp. 399-416.

161. Ministerio del Interior y Seguridad Pública. Ley 20.678. Establece la Elección Directa de los Consejeros Regionales; Ministerio del Interior y Seguridad Pública: Santiago, Chile, 2013.

162. Ministerio del Interior y Seguridad Pública. Ley 21.074. Fortalecimiento de la Regionalización del País; Ministerio del Interior y Seguridad Pública: Santiago, Chile, 2018.

163. Aroca, P.; Fierro, P. Concentración y Centralismo: Una Mirada Territorial a Nuestra Crisis. Available online: https://www. ciperchile.cl/2020/09/05/concentracion-y-centralismo-una-mirada-territorial-a-nuestra-crisis/ (accessed on 14 November 2021).

164. Servicio de Impuestos Internos (SII). Distribución Empresas. 2017. Available online: https://www.sii.cl/destacados/ogp/ distribucionempresas_estadisticas2017.html (accessed on 18 August 2021).

165. Urbina, M.A.; Guerrero, P.C.; Jerez, V.; Lison, F.; Luna-Jorquera, G.; Matus-Olivares, C.; Ortiz, J.C.; Pavez, G.; Perez-Alvarez, M.J.; Riquelme-Bugueno, R.; et al. Extractivist policies hurt Chile's ecosystems. Science 2021, 373, 1208-1209. [CrossRef] [PubMed]

166. BirdLife International. Spheniscus Humboldti. The International Union for the Conservation of Nature (IUCN) Red List of Threatened Species. 2020. Available online: https:/ / www.iucnredlist.org/species/22697817/182714418 (accessed on 14 November 2021).

167. Palacios, C. Cientos de Personas se Manifiestan en La Serena y Coquimbo en Rechazo a Dominga. Available online: https: / www. latercera.com/nacional/noticia/cientos-de-personas-se-manifiestan-en-la-serena-y-coquimbo-en-rechazo-a-dominga/V7M5 KBH6HRASJABPHV4WT4PDPY/ (accessed on 1 October 2021).

168. Kaya, Ö. On the Way to a New Constitution in Turkey. Constitutional History, Political Parties and Civil Platforms. Available online: https: / /library.fes.de/pdf-files/bueros/tuerkei/12220.pdf (accessed on 14 November 2021).

169. May, J.R.; Daly, E. Emerging environmental constitutionalism. In Global Environmental Constitutionalism; May, J.R., Daly, E., Eds.; Cambridge University Press: Cambridge, UK, 2014. [CrossRef]

170. Abubaker, J.; Cederlund, H.; Arthurson, V.; Pell, M. Bacterial community structure and microbial activity in different soils amended with biogas residues and cattle slurry. Appl. Soil Ecol. 2013, 72, 171-180. [CrossRef]

171. May, J.R.; Daly, E. Judicial Handbook on Environmental Constitutionalism; UNEP: Nairobi, Kenya, 2017.

172. González Farfán, C. Los Grupos detrás de la Convención Que Aportarán Evidencia Científica Para una Constitución Ecológica. Available online: https:/ / www.paiscircular.cl/medio-ambiente/los-grupos-detras-de-la-convencion-que-aportaran-evidenciacientifica-hacia-una-constitucion-ecologica/ (accessed on 14 November 2021).

173. El Mostrador. Red de Constitucionalismo Ecológico Propone la Protección y Valoración de la Biodiversidad en Centro del Debate Constitucional. Available online: https:/ / www.elmostrador.cl/noticias/pais/2021/01/21/red-de-constitucionalismo-ecologicopropone-la-proteccion-y-valoracion-de-la-biodiversidad-en-centro-del-debate-constitucional/ (accessed on 14 November 2021).

174. Corporación Fiscalía del Medio Ambiente (FIMA). Bases Para una Constitución Ecológica. Available online: https:/ /www.fima.cl/ wordpress/wp-content/uploads/2020/11/bases-para-una-constitución-ecológica-v.-25.11.20-1.pdf (accessed on 14 November 2021). 
175. Chapin, F.S.; Pickett, S.T.A.; Power, M.E.; Jackson, R.B.; Carter, D.M.; Duke, C. Earth stewardship: A strategy for social-ecological transformation to reverse planetary degradation. J. Environ. Sci. Stud. 2011, 1, 44-53. [CrossRef]

176. Collins, L. The Ecological Constitution: Reframing Environmental Law; Routledge: New York, NY, USA, 2021.

177. Red de Constitucionalismo Ecológico. Una Constitución Socioecológica para Chile: Propuestas Integradas; Galdámez, L., Millaléo, S., Saavedra, B., Eds.; Red de Constitucionalismo Ecológico: Santiago, Chile, 2021.

178. Pauta. Así Quedó Conformada la Convención Constituyente. Available online: https://www.pauta.cl/politica/convencionconstituyente-155-escanos-resultados (accessed on 14 November 2021).

179. Cornejo, C. Elisa Loncón, Presidenta de la Convención Constitucional: “Esta es la Primera Muestra Que Esta Convención va a Ser Participativa". Available online: https://www.latercera.com/politica/noticia/elisa-loncon-presidenta-de-la-convencionconstitucional-esta-es-la-primera-muestra-que-esta-convencion-va-a-ser-participativa/KHXYMUVRDVHA3E4ZH6OEUBCB2I/ (accessed on 14 November 2021).

180. Latorre, R.; Rivas, S. La Paradoja de la Paridad: Correcciones Favorecen a más Hombres Que a Mujeres. Available online: https:/ / www.latercera.com/politica/noticia/la-paradoja-de-la-paridad-correcciones-favorecen-a-mas-hombres-que-a-mujeres / GZXTRJ3DKJFRJCIWEU4OBI7UUM/ (accessed on 14 November 2021).

181. Ministerio de Obras Públicas (MOP). Atlas del Agua, Chile. 2016. Available online: http://www.dga.cl/DGADocumentos/ Atlas2016parte1-17marzo2016b.pdf (accessed on 14 November 2021).

182. Luebert, F.; Pliscoff, P. Sinopsis Bioclimática y Vegetacional de Chile; Editorial Universitaria: Santiago, Chile, 2006.

183. Casanova, M.; Salazar, O.; Seguel, O.; Luzio, W. The Soils of Chile; Springer-Dordrecht: Dordrecht, The Netherlands, 2013 ; p. 185.

184. Espinosa, C. Interpretive affinities: The constitutionalization of rights of nature, Pacha Mama, in Ecuador. J. Environ. Policy Plan. 2015, 21, 608-622. [CrossRef]

185. Kotzé, L.J.; Villavicencio Calzadilla, P. Somewhere between rhetoric and reality: Environmental constitutionalism and the rights of nature in Ecuador. Transnatl. Environ. Law 2017, 6, 401-433. [CrossRef]

186. Meisels, T. Territorial Rights; Springer: Berlin/Heidelberg, Germany, 2009. [CrossRef]

187. Mancilla, A. Review Article: The environmental turn in territorial rights. Crit. Rev. Int. Soc. Polit. Philos. 2014, 19, 221-241. [CrossRef]

188. Martínez-Tilleria, K.; Núñez-Ávila, M.; León, C.A.; Pliscoff, P.; Squeo, F.A.; Armesto, J.J. A framework for the classification Chilean terrestrial ecosystems as a tool for achieving global conservation targets. Biodivers. Conserv. 2017, 26, 2857-2876. [CrossRef]

189. Dasgupta, P. The Economics of Biodiversity: The Dasgupta Review. Abridged Version; HM Treasury: London, UK, 2021.

190. World Economic Forum. The Global Risks Report 2020; World Economic Forum: Cologny, Switzerland, 2020.

191. Costanza, R.; d'Arge, R.; de Groot, R.; Farber, S.; Grasso, M.; Hannon, B.; Limburg, K.; Naeem, S.; O’Neill, R.V.; Paruelo, J.; et al. The value of the world's ecosystem services and natural capital. Nature 1997, 387, 253-260. [CrossRef]

192. Miller, D. Territorial rights: Concept and justification. Polit. Stud. 2011, 60, 252-268. [CrossRef]

193. Romero-Toledo, H.; Gutiérrez, F. Conflictos socioterritoriales mineros: La expansión minera y la articulación identitaria indígena en el Norte Grande de Chile. In Mineração na America Latina: Neoextrativismo e Lutas Territoriais; Zhouri, A., Bolados, P., Castro, E., Eds.; Annablume: Sao Paulo, Brazil, 2016; pp. 67-89.

194. Romero-Toledo, H.; Videla, A.; Gutiérrez, F. Explorando conflictos entre comunidades indígenas y la industria minera en Chile: Las transformaciones socioambientales de la región de Tarapacá y el caso de Lagunillas. Estudios Atacameños 2017, 55, 231-250. [CrossRef]

195. Economic Commission for Latin America and the Caribbean (ECLAC). Guaranteeing Indigenous People's Rights in Latin America. Progress in the Past Decade and Remaining Challenges; ECLAC: Santiago, Chile, 2014.

196. Orellana Ossandón, A.; Arenas Vásquez, F.; Moreno Alba, D. Ordenamiento territorial en Chile: Nuevo escenario para la gobernanza regional. Rev. Geogr. Norte Gd. 2020, 31-49. [CrossRef]

197. Nuñez, A. El país de las cuencas: Fronteras en movimient e imaginarios territoriales en la construcción de la nación. Chile, siglos XVIII-XIX. In Proceedings of the XII Coloquio Internacional de Geocrítica, Universidad Nacional de Colombia, Bogotá, Colombia, 7-11 May 2012; p. 16.

198. United States Environmental Protection Agency (US EPA). Handbook for Developing Watershed Plans to Restore and Protect Our Waters; US EPA: Washington, DC, USA, 2008.

199. Dirección General de Aguas (DGA). Inventario de Cuencas, Subcuencas, y Subsubcuencas de Chile; DGA: Santiago, Chile, $2014 ;$ p. 54.

200. Dirección General de Aguas, Límites Cuencas. Available online: https://www.ide.cl/index.php/medio-ambiente/item/ 1678-limites-cuencas (accessed on 14 November 2021).

201. Ministerio del Medio Ambiente. Formaciones Vegetacionales Gajardo. Available online: https://www.ide.cl/index.php/flora-yfauna/item/1515-formaciones-vegetacionales-gajardo (accessed on 14 November 2021).

202. Hunold, C. Canada's Low-level Radioactive Waste Disposal Problem: Voluntarism Reconsidered. Environ. Polit. 2002, 11, 49-72. [CrossRef]

203. Del Monte-Luna, P.; Brook, B.W.; Zetina-Rejón, M.J.; Cruz-Escalona, V.H. The carrying capacity of ecosystems. Glob. Ecol. Biogeogr. 2004, 13, 485-495. [CrossRef]

204. Initiative $20 \times 20$. Chile. Available online: https:/ / initiative20x20.org/regions-countries/chile (accessed on 25 August 2021).

205. New Zealand Legislation. Te Awa Tupua (Whanganui River Claims Settlement) Act 2017. Available online: https://www. legislation.govt.nz/act/public/2017/0007/latest/whole.html (accessed on 14 November 2021). 